\title{
Heat Flow in the Campos Sedimentary Basin and Thermal History of the Continental Margin of Southeast Brazil
}

\author{
Roberta A. Cardoso ${ }^{1,2}$ and Valiya M. Hamza ${ }^{1}$ \\ ${ }^{1}$ Observatório Nacional-ON/MCT, Rio de Janeiro, Brazil \\ ${ }^{2}$ Superintendence for Petroleum and Gas/DPG, Empresa de Pesquisa Energética (EPE), Rio de Janeiro, Brazil \\ Correspondence should be addressed to Valiya M. Hamza; hamza@on.br
}

Received 21 February 2014; Accepted 27 March 2014; Published 27 April 2014

Academic Editors: E. Liu and A. Tzanis

Copyright (c) 2014 R. A. Cardoso and V. M. Hamza. This is an open access article distributed under the Creative Commons Attribution License, which permits unrestricted use, distribution, and reproduction in any medium, provided the original work is properly cited.

\begin{abstract}
Bottom-hole temperatures and physical properties derived from geophysical logs of deep oil wells have been employed in assessment of the geothermal field of the Campos basin, situated in the continental margin of southeast Brazil. The results indicate geothermal gradients in the range of 24 to $41^{\circ} \mathrm{C} / \mathrm{km}$ and crustal heat flow in the range of 30 to $100 \mathrm{~mW} / \mathrm{m}^{2}$ within the study area. Maps of the regional distributions of these parameters point to arc-shaped northeast-southwest trending belts of relatively high gradients and heat flow in the central part of the Campos basin. This anomalous geothermal belt is coincident with the areas of occurrences of oil deposits. The present study also reports progress obtained in reconstructing the subsidence history of sedimentary strata at six localities within the Campos basin. The results point to episodes of crustal extension with magnitudes of 1.3 to 2 , while extensions of subcrustal layers are in the range of 2 to 3. Thermal models indicate high heat flow during the initial stages of basin evolution. Maturation indices point to depths of oil generation greater than $3 \mathrm{~km}$. The age of peak oil generation, allowing for variable time scales for cooling of the extended lithosphere, is found to be less than $40 \mathrm{Ma}$.
\end{abstract}

\section{Introduction}

The continental margin of southeast Brazil is composed of three major sedimentary basins: Espirito Santo, Campos, and Santos (e.g., [1-3]). The structural highs of Victoria and Cabo Frio are usually considered as representing the limits of the Campos basin in the continental platform region. The submerged parts of this basin have an area of approximately $100.000 \mathrm{~km}^{2}$, while that of its continental part is only $500 \mathrm{~km}^{2}$. The relative locations of these basin segments are indicated in the map of Figure 1. The Campos basin is the most prolific oil producing basin in the western South Atlantic, with more than sixty hydrocarbon accumulations, currently accounting for about $80 \%$ of Brazilian oil production. The locations of the main oil fields of the Campos basin are indicated as green colored areas in the map of Figure 1. Note that most of the known oil fields are located in the central rift zone of the Campos basin.

Most of the earlier studies on the geothermal field of the Campos basin have been based on results of bottom-hole temperature measurements in oil exploration wells (e.g., [46]). Ross and Pantoja [7] reported results of a work with focus on local subsurface temperature fields. Jahnert [8] presented maps of regional variations deep isotherms and thermal gradients in areas of oil fields and discussed their eventual correlations with regional scale structural features and gravity anomalies. Unfortunately, the details of data base employed by $[7,8]$ are not available for public domain analysis. In addition, very little information is available in these reports on the methods employed in data reduction and error analysis. In fact, Cardoso and Hamza [9] pointed out to potential systematic errors in earlier calculations of geothermal gradients, arising from the use of inappropriate values for ocean bottom temperatures. Such problems turned out to be major obstacles in carrying out independent assessments of earlier works on the thermal field of the Campos basin.

More recently, Gomes and Hamza [10] reported geothermal data for the adjacent coastal region of Rio de Janeiro. In addition, Vieira et al. [11] and Vieira and Hamza [12] reported 


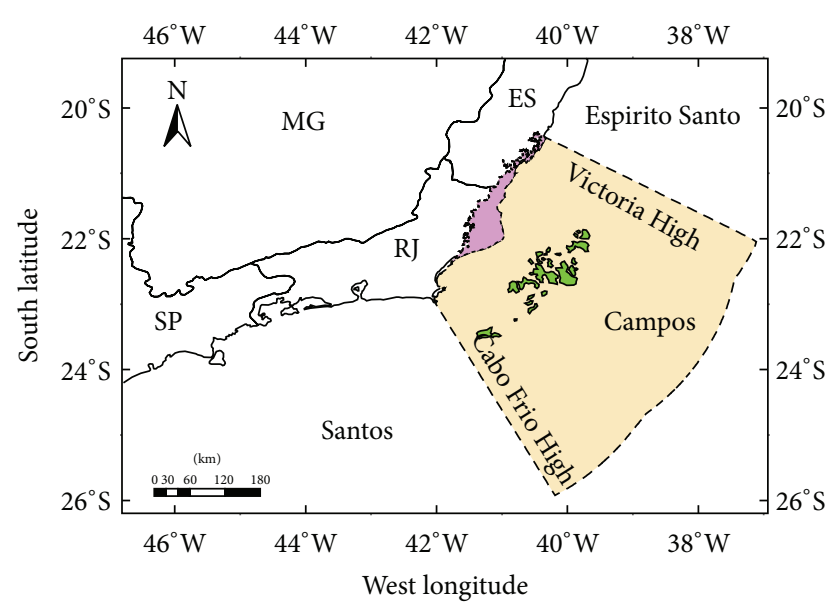

FIgURE 1: Locations of sedimentary basins (Santos, Campos, and Espirito Santo) in the continental margin of southeast Brazil. The ash and pink colored areas indicate the onshore and offshore segments of the Campos basin and the dotted lines their approximate limits. The green colored patches are locations of the main oil fields in the Campos basin.

estimates of heat flow values for the oceanic crust adjacent to the Campos basin. In this context, the focus of the present work is on the analysis of updated geothermal data for the offshore segment of the Campos basin that also take into consideration the supplementary data sets for the oceanic and continental areas. The purpose is to gain better insights into the thermal structure of the continental margin of southeast Brazil. The present work also examines the implications of the results of this new analysis in improving the assessments of thermal maturation indices of sedimentary strata in the Campos basin.

\section{Geologic Context}

According to interpretations of geologic data, the stratigraphic and structural evolution of the Campos basin has been strongly influenced by the breakup of the Pangaea super continent and formation of oceanic crust between South American and African lithospheric plates (e.g., [1319]). Subsequent development of the basin seems to have been determined by stretching and thinning events of the local crust. There are indications of an initial short-period phase of fault-controlled subsidence, followed by a relatively long period of thermal subsidence (e.g., [20-23]). Several studies have been carried out on the structural framework of the continental shelf and upper slope of the Brazilian marginal basins, describing faults, structural alignments, and extension of fracture zones (e.g., [15, 17, 21, 24]). Ponte and Asmus [25] provide a summary of geologic knowledge regarding these features, emphasizing their structural-stratigraphic framework and tectonic evolution. According to these studies (see also $[26,27])$, the main phases to be considered in the evolution of the Brazilian marginal basins are prerift, rift, transitional, and drift. During the prerift phase (Late Jurassic to Early Cretaceous), continental sediments were deposited in peripheral intracratonic basins. In the rift phase (during Early Cretaceous), the breakup of the continental crust of the Gondwana continent gave rise to a central graben and rift valleys where lacustrine sediments were deposited. The transitional phase (during Aptian) developed under relative tectonic stability, when evaporitic and clastic lacustrine sequences were deposited. In the drift phase (during Albian to Holocene), a regional homoclinal structure developed, consisting of two distinct sedimentary sequences, a lower clastic-carbonate and an upper clastic.

Seismic surveys have identified the presence of structures in deep strata, which have been interpreted as intrusive magmatic activities of early Tertiary times. Several geologic studies (e.g., [27-29]) have pointed out evidences of the occurrence of sporadic magmatic activity during the Eocene and Santonian-Campanian. Volcanic building associated with intrusive and extrusive rocks has been observed that have local impacts on the mineralogical and sedimentary composition of the siliciclastic deposits [30]. Occurrences of subaerial and subaqueous volcanism are well identified and its characteristics are described in terms of seismic, log, and lithologic evidences [31]. However, no evidences have been found of volcanic or magmatic activities since Miocene times. Also, there are no reports of occurrences of hydrothermal fluid circulation processes in the ocean floor. The main rock formations of the Campos basin, episodes of tectonothermal activities, and their respective ages are listed in Table 1.

The hydrocarbon accumulations are distributed throughout the stratigraphic column of the basin, from Neocomian to Miocene. The reservoirs range from fractured basalts and porous bioclastic limestone (coquinas) in the Lagoa Feia Group to limestone and sandstone in the Macaé Group and sandstones in the Campos Group. Detailed geochemical analyses show that almost all the hydrocarbon accumulations discovered to date originate mainly from lacustrine calcareous black shale deposited in a closed Upper Neocomian lake system.

\section{Temperature and Heat Flow Data}

Information on geothermal characteristics of subsurface layers in the study area is derived almost exclusively on bottom-hole temperature (BHT) data acquired in boreholes and oil wells, in addition to sea floor temperature data in oceanic regions of the Campos basin. Given below are brief descriptions of the data sets compiled and procedures adopted in the determination of geothermal gradients and heat flow in the study area.

3.1. Sea Floor Temperatures. The oceanographic data sets provided by the Directorate of Hydrograph and Navigation (DHN) [32] of the Brazilian Navy have been useful in determining sea water temperatures in the coastal area of southeast Brazil. The relative accuracy of sensors used in deep sea water temperature measurements is often considered as better than $0.1^{\circ} \mathrm{C}$.

Analysis of these data sets points to the presence of systematic trends of decreasing temperatures with depth of 
TABLE 1: Sedimentary formations in the Campos and Santos basins (modified after [76]) and periods of main thermal activity.

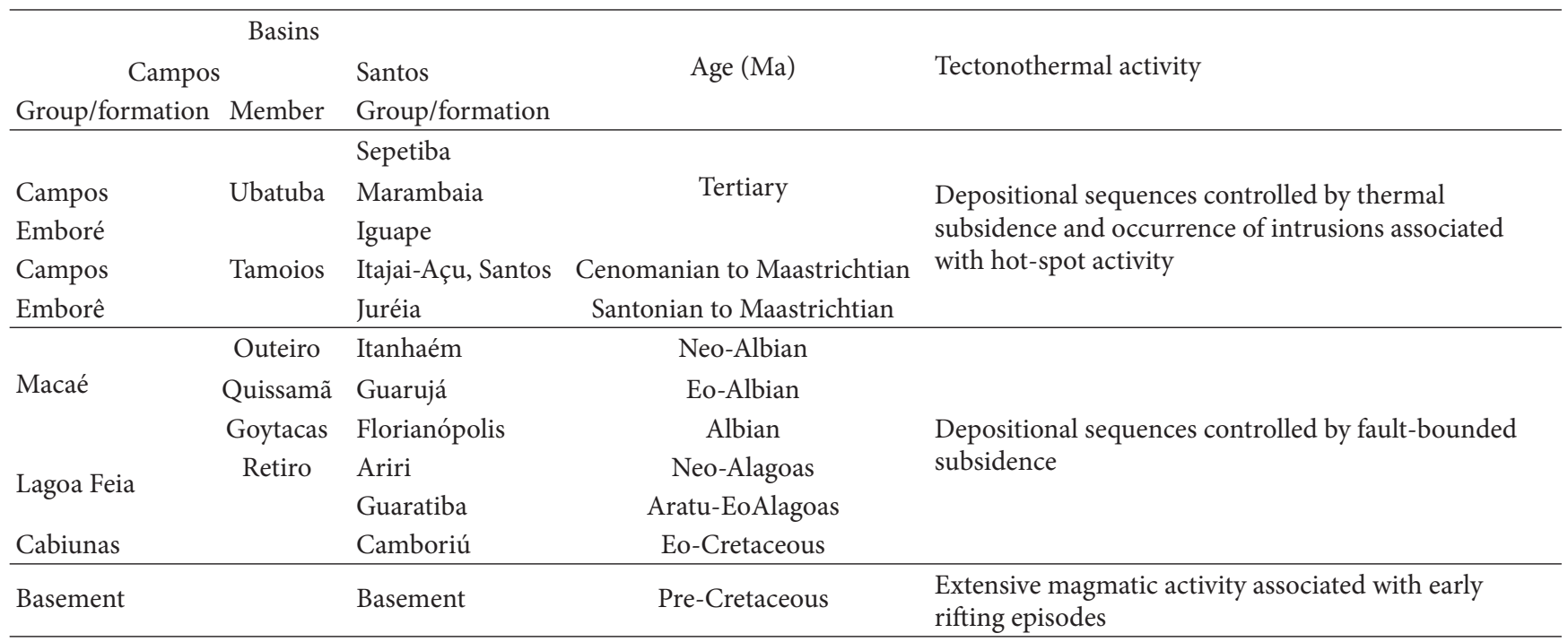

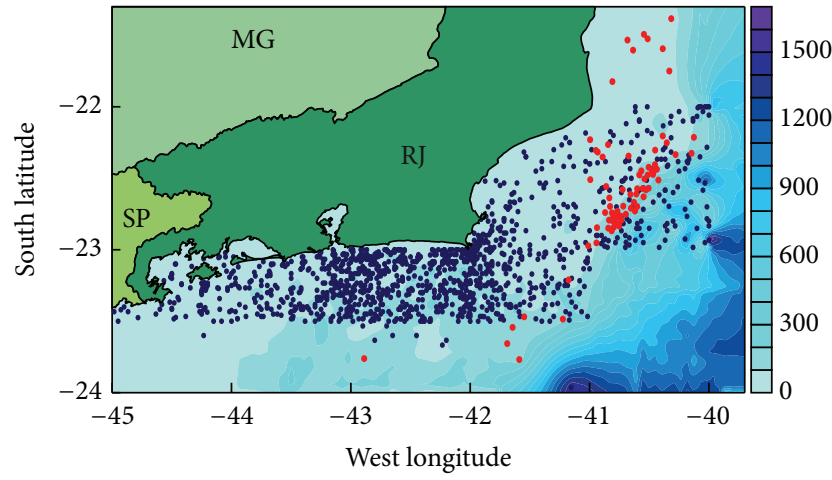

FIgURE 2: Locations of sea floor temperature measurements (indicated as blue dots) in the bathymetry map of the coastal area of southeast Brazil. The red dots refer to locations of oil wells with BHT measurements reported in the present work. The side bar indicates sea floor depth in meters.

sea floor in the study area. The rates of decrease are relatively high at depths less than 100 meters but drop sharply at deeper levels. At depths of more than 200 meters, the rate of decrease in water temperatures is found to be less than $0.02^{\circ} \mathrm{C} / \mathrm{m}$. Under such conditions, temperatures measured in the lower parts of the water column close to the sea floor are nearly identical to temperatures at the sediment-water interface at the sea floor. Hence, shallow water temperature data sets can be used to obtain approximate estimates of the temperatures of the sea floor. In the present work, data sets for the continental platform area of southeast Brazil have been employed in deriving an empirical relation between the height of the water column $(z)$ and temperatures at the sea floor (SFT):

$$
\begin{aligned}
\text { SFT }= & 8 \times 10^{-9} z^{3}+3 \times 10^{-6} z^{2} \\
& -3.01 \times 10^{-2} z+22.505 .
\end{aligned}
$$

Equation (1) was used in determination of sea floor temperatures at more than 1,360 localities in the Campos basin. Illustrated in the map of Figure 2 are the locations of oil wells in which BHT measurements have been carried out.

3.2. BHT Data for Oil Wells. Zembruscki [33] reported bottom-hole temperature (BHT) data for 96 oil wells in the area of the Campos basin. Most of such wells are terminated at the depths hydrocarbon reservoirs, usually in the range of 2,000 to 3,500 meters. The locations of a selected set of 76 wells are indicated in the map of Figure 2 along with the sites of sea floor temperature measurements. The sensors employed in BHT measurements have accuracies of no better than $1^{\circ} \mathrm{C}$.

Analysis of the details of this data set revealed some difficulties in the determination of temperature gradients. In most cases, the records make reference to single temperature measurement at the bottom of selected wells. In such cases, it is common practice to make use of available information on sea floor temperatures in the determination of gradient values. In the present work, results of oceanographic studies in the coastal area of southeast Brazil (discussed in the previous section) were employed in determination of temperatures at the sediment-water interface.

Another difficulty with the BHT data reported in [33] is that it does not provide auxiliary information necessary for incorporating corrections for drilling disturbances. Hence, the empirical correction procedure of AAPG [34] was selected as the best option available. Procedures for such corrections have been discussed extensively in the literature (see, e.g., [35]). Use of AAPG method has been found to lead to corrections in BHT values of less than $10 \%$, but, for wells with depths greater than 1000 meters, alterations in temperature gradient values are found to be less than $5 \%$ (see, e.g., [36]). Similar conclusions were also reached by [37] in the analysis of BHT data for the Anadarko basin (southern USA) and by [38] Blackwell and Richards (2004) 
TABLE 2: Summary of measured and AAPG corrected bottom-hole temperatures for 76 oil wells in the Campos basin. Values in the 7th column refer to estimated errors in BHT. The last two columns provide depths of water column $\left(Z_{\mathrm{SF}}\right)$ and sea floor temperatures $\left(T_{\mathrm{SF}}\right)$ at the sites of wells.

\begin{tabular}{|c|c|c|c|c|c|c|c|c|}
\hline \multirow{2}{*}{ Well ID } & \multirow{2}{*}{ Latitude } & \multirow{2}{*}{ Longitude } & \multirow{2}{*}{$\begin{array}{c}\text { Depth } \\
(\mathrm{m})\end{array}$} & \multicolumn{3}{|c|}{$\mathrm{BHT}\left({ }^{\circ} \mathrm{C}\right)$} & \multirow{2}{*}{$\begin{array}{l}Z_{\mathrm{SF}} \\
(\mathrm{m})\end{array}$} & \multirow{2}{*}{$\begin{array}{l}T_{\mathrm{SF}} \\
\left({ }^{\circ} \mathrm{C}\right)\end{array}$} \\
\hline & & & & Measured & Corrected & Error & & \\
\hline 1-RJS-5B & -22.2042 & -40.3867 & 3897 & 111.1 & 124.4 & 6.2 & 80 & 16.4 \\
\hline 1-RJS-13 & -22.6970 & -40.8284 & 2209 & 67.8 & 75.1 & 3.8 & 90 & 16.2 \\
\hline 1-RJS-23 & -22.6376 & -40.8345 & 2972 & 85.6 & 96.0 & 4.8 & 93 & 16.1 \\
\hline 1-RJS-26 & -22.5577 & -40.8612 & 2585 & 72.2 & 81.1 & 4.1 & 71 & 16.7 \\
\hline 1-RJS-27 & -22.2646 & -40.8448 & 1687 & 66.7 & 71.9 & 3.6 & 56 & 17.1 \\
\hline 1-RJS-28A & -22.7517 & -40.6958 & 2672 & 81.7 & 90.9 & 4.5 & 145 & 14.8 \\
\hline 1-RJS-32 & -22.5125 & -40.4232 & 3825 & 111.7 & 124.8 & 6.2 & 298 & 12.2 \\
\hline 1-RJS-33 & -23.7614 & -42.8883 & 3135 & 87.8 & 98.8 & 4.9 & 149 & 14.7 \\
\hline 1-RJS-36 & -22.3514 & -40.8904 & 1951 & 65.6 & 71.9 & 3.6 & 56 & 17.1 \\
\hline 1-RJS-38 & -22.7094 & -40.6531 & 2848 & 88.9 & 98.8 & 4.9 & 180 & 14.1 \\
\hline 1-RJS-41 & -22.6953 & -40.7176 & 3541 & 107.2 & 119.6 & 6.0 & 108 & 15.7 \\
\hline 4-RJS-42 & -22.4372 & -40.4360 & 3359 & 96.1 & 107.9 & 5.4 & 136 & 15.0 \\
\hline 1-RJS-43 & -22.7396 & -40.8700 & 3530 & 95.0 & 107.3 & 5.4 & 100 & 15.9 \\
\hline 1-RJS-44 & -22.6128 & -40.6573 & 2804 & 97.8 & 107.6 & 5.4 & 118 & 15.5 \\
\hline 1-RJS-45 & -22.6980 & -40.6007 & 3282 & 89.4 & 100.9 & 5.0 & 284 & 12.4 \\
\hline 1-RJS-46 & -22.4773 & -40.5134 & 3344 & 95.6 & 107.4 & 5.4 & 125 & 15.3 \\
\hline 1-RJS-47E & -22.5792 & -40.7234 & 3819 & 116.7 & 129.8 & 6.5 & 105 & 15.8 \\
\hline 1-RJS-48 & -22.3053 & -40.9468 & 3545 & 110.0 & 122.4 & 6.1 & 50 & 17.3 \\
\hline 1-RJS-49 & -22.7846 & -40.8009 & 3192 & 88.9 & 100.1 & 5.0 & 105 & 15.8 \\
\hline 1-RJS-50 & -22.4540 & -40.4731 & 3218 & 107.2 & 118.5 & 5.9 & 132 & 15.1 \\
\hline 1-RJS-52 & -22.2519 & -40.3531 & 3520 & 107.2 & 119.5 & 6.0 & 130 & 15.2 \\
\hline 1-RJS-53 & -22.6296 & -40.5474 & 3300 & 90.6 & 102.2 & 5.1 & 284 & 12.4 \\
\hline 1-RJS-54 & -22.5700 & -40.5058 & 3494 & 101.7 & 113.9 & 5.7 & 254 & 12.8 \\
\hline 4-RJS-55 & -22.8131 & -40.7775 & 3075 & 77.8 & 88.6 & 4.4 & 114 & 15.6 \\
\hline 1-RJS-56 & -21.5938 & -40.3867 & 5000 & 154.4 & 168.1 & 8.4 & 32 & 17.8 \\
\hline 1-RJS-57 & -21.4934 & -40.5444 & 4202 & 148.3 & 162.1 & 8.1 & 28 & 17.9 \\
\hline 1-RJS-58 & -21.6038 & -40.6354 & 3796 & 125.0 & 138.1 & 6.9 & 24 & 18.0 \\
\hline 3-RJS-59 & -22.4731 & -40.4689 & 3252 & 99.4 & 110.8 & 5.5 & 150 & 14.7 \\
\hline 1-RJS-60 & -22.4050 & -40.4520 & 3704 & 109.4 & 122.2 & 6.1 & 118 & 15.5 \\
\hline 4-RJS-62A & -22.7722 & -40.7675 & 3201 & 87.8 & 99.1 & 5.0 & 109 & 15.7 \\
\hline 1-RJS-63A & -22.7945 & -40.7344 & 3206 & 80.0 & 91.3 & 4.6 & 122 & 15.4 \\
\hline 1-RJS-64A & -22.8344 & -40.7518 & 3205 & 81.1 & 92.4 & 4.6 & 132 & 15.1 \\
\hline 1-RJS-65 & -22.7305 & -40.7669 & 3449 & 97.2 & 109.3 & 5.5 & 103 & 15.8 \\
\hline 1-RJS-66 & -22.3251 & -40.1457 & 4490 & 128.9 & 143.0 & 7.1 & 200 & 13.7 \\
\hline 1-RJS-68 & -22.9722 & -41.0108 & 2667 & 80.6 & 89.8 & 4.5 & 98 & 16.0 \\
\hline 1-RJS-69 & -22.5098 & -40.9939 & 2297 & 77.2 & 84.9 & 4.2 & 57 & 17.1 \\
\hline 1-RJS-70 & -22.2301 & -40.9954 & 2355 & 83.3 & 91.2 & 4.6 & 39 & 17.6 \\
\hline 1-RJS-71 & -22.3170 & -40.9319 & 3504 & 106.7 & 119.0 & 5.9 & 54 & 17.2 \\
\hline 1-RJS-73 & -22.7714 & -40.8014 & 3187 & 91.1 & 102.3 & 5.1 & 130 & 15.2 \\
\hline 1-RJS-74 & -22.7512 & -40.7989 & 3189 & 99.4 & 110.6 & 5.5 & 101 & 15.9 \\
\hline 1-RJS-75 & -22.3034 & -40.4504 & 3605 & 109.4 & 122.0 & 6.1 & 106 & 15.8 \\
\hline 1-RJS-76 & -22.5733 & -40.6008 & 4870 & 134.4 & 148.3 & 7.4 & 122 & 15.4 \\
\hline 1-RJS-78 & -22.7419 & -40.8122 & 3240 & 98.3 & 109.7 & 5.5 & 110 & 15.7 \\
\hline 1-RJS-79 & -21.5245 & -40.5132 & 3761 & 133.9 & 146.9 & 7.3 & 26 & 18.0 \\
\hline 3-RJS-80 & -22.4446 & -40.4783 & 3170 & 102.8 & 114.0 & 5.7 & 121 & 15.4 \\
\hline 1-RJS-82 & -21.8235 & -40.8087 & 2282 & 86.1 & 93.7 & 4.7 & 24 & 18.0 \\
\hline
\end{tabular}


TABLe 2: Continued.

\begin{tabular}{|c|c|c|c|c|c|c|c|c|}
\hline \multirow{2}{*}{ Well ID } & \multirow{2}{*}{ Latitude } & \multirow{2}{*}{ Longitude } & \multirow{2}{*}{$\begin{array}{c}\text { Depth } \\
(\mathrm{m})\end{array}$} & \multicolumn{3}{|c|}{$\mathrm{BHT}\left({ }^{\circ} \mathrm{C}\right)$} & \multirow{2}{*}{$\begin{array}{l}Z_{\mathrm{SF}} \\
(\mathrm{m})\end{array}$} & \multirow{2}{*}{$\begin{array}{l}T_{\mathrm{SF}} \\
\left({ }^{\circ} \mathrm{C}\right)\end{array}$} \\
\hline & & & & Measured & Corrected & Error & & \\
\hline 1-RJS-83 & -22.5043 & -40.5401 & 3252 & 106.1 & 117.5 & 5.9 & 124 & 15.3 \\
\hline 1-RJS-84 & -22.4229 & -40.5046 & 3326 & 105.0 & 116.7 & 5.8 & 115 & 15.5 \\
\hline 1-RJS-85 & -22.6102 & -40.6079 & 3994 & 118.3 & 131.8 & 6.6 & 141 & 14.9 \\
\hline 1-RJS-88 & -22.4628 & -40.4658 & 3257 & 99.4 & 110.9 & 5.5 & 170 & 14.3 \\
\hline 1-RJS-89 & -22.8458 & -40.9379 & 2760 & 86.1 & 95.7 & 4.8 & 117 & 15.5 \\
\hline 1-RJS-90 & -22.3342 & -40.2792 & 3503 & 103.3 & 115.6 & 5.8 & 126 & 15.3 \\
\hline 1-RJS-91 & -23.2109 & -41.1755 & 2890 & 95.6 & 105.7 & 5.3 & 111 & 15.6 \\
\hline 1-RJS-92 & -22.7929 & -40.8364 & 3127 & 91.1 & 102.1 & 5.1 & 99 & 15.9 \\
\hline 1-RJS-93 & -22.8412 & -40.7963 & 2988 & 90.0 & 100.5 & 5.0 & 115 & 15.5 \\
\hline 1-RJS-94 & -21.5334 & -40.6822 & 2704 & 111.1 & 120.5 & 6.0 & 23 & 18.1 \\
\hline 1-RJS-95 & -22.6685 & -40.6278 & 4439 & 128.9 & 143.0 & 7.1 & 179 & 14.1 \\
\hline 1-RJS-96A & -21.3834 & -40.3158 & 4003 & 144.4 & 157.9 & 7.9 & 53 & 17.2 \\
\hline 1-RJS-97C & -21.7498 & -40.3318 & 3992 & 121.7 & 135.2 & 6.8 & 46 & 17.4 \\
\hline 1-RJS-99 & -23.7681 & -41.5889 & 4245 & 107.2 & 121.1 & 6.1 & 154 & 14.6 \\
\hline 1-RJS-100 & -23.5431 & -41.6448 & 3122 & 84.4 & 95.4 & 4.8 & 146 & 14.8 \\
\hline 1-RJS-101 & -22.4765 & -40.5828 & 4603 & 167.2 & 181.3 & 9.1 & 114 & 15.6 \\
\hline 1-RJS-102A & -22.4480 & -40.5660 & 5049 & 152.2 & 165.8 & 8.3 & 108 & 15.7 \\
\hline 1-RJS-105 & -23.4693 & -41.5478 & 3380 & 103.9 & 115.8 & 5.8 & 131 & 15.2 \\
\hline 1-RJS-106 & -22.7641 & -40.7404 & 2780 & 99.4 & 109.1 & 5.5 & 115 & 15.5 \\
\hline 1-RJS-107 & -23.6564 & -41.6900 & 3898 & 118.9 & 132.2 & 6.6 & 150 & 14.7 \\
\hline 1-RJS-108 & -22.3445 & -40.6733 & 4958 & 147.2 & 161.0 & 8.0 & 67 & 16.8 \\
\hline 1-RJS-111 & -22.7978 & -40.8058 & 3168 & 96.1 & 107.2 & 5.4 & 130 & 15.2 \\
\hline 1-RJS-113 & -22.9523 & -40.9423 & 2971 & 85.0 & 95.4 & 4.8 & 100 & 15.9 \\
\hline 1-RJS-114 & -22.8488 & -40.8432 & 3072 & 95.0 & 105.8 & 5.3 & 112 & 15.6 \\
\hline 1-RJS-115 & -22.8682 & -40.8145 & 3096 & 84.4 & 95.3 & 4.8 & 113 & 15.6 \\
\hline 1-RJS-116 & -22.7294 & -40.6195 & 3990 & 118.3 & 131.8 & 6.6 & 296 & 12.2 \\
\hline 1-RJS-117 & -22.2137 & -40.1260 & 4087 & 114.4 & 128.1 & 6.4 & 119 & 15.4 \\
\hline 3 -RJS-120 & -22.5806 & -40.5271 & 3180 & 98.9 & 110.1 & 5.5 & 233 & 13.1 \\
\hline 4-RJS-121 & -22.5718 & -40.5546 & 3217 & 96.1 & 107.4 & 5.4 & 178 & 14.1 \\
\hline 1-RJS-125 & -23.4852 & -41.2235 & 2496 & 81.1 & 89.6 & 4.5 & 168 & 14.3 \\
\hline
\end{tabular}

in the discussion of error estimates in the heat flow map of North America.

In the present work, corrections to BHT values were made using the relation

$$
\Delta T=a z+b z^{2}-c z^{3}-d z^{4},
$$

where $\Delta T$ is the correction for temperature, $z$ is the depth in meters, and $a, b, c$, and $d$ are the polynomial coefficients with values of $1.878 \times 10^{-3}, 8.476 \times 10^{-7}, 5.091 \times 10^{-11}$, and 1.681 $\times 10^{-14}$, respectively. The details of data on well depths and bottom-hole temperatures are provided in Table 2, along with AAPG corrected values and estimates of errors in the relevant correction procedure. Also, given in this table are data on thicknesses of water columns and sea floor temperatures at the sites of wells along with complementary information on locations and well identification.

3.3. Geothermal Gradients. Geothermal gradients values were calculated for sites of 76 oil wells considered in the present work. The relation used in determination of gradient values $(\Gamma)$ for sites of oil wells is

$$
\Gamma=\frac{T_{\mathrm{BHT}}-T_{\mathrm{SF}}}{Z_{\mathrm{BHT}}-Z_{\mathrm{SF}}}
$$

where $T_{\mathrm{BHT}}$ is the corrected bottom-hole temperature at depth $Z_{\mathrm{BHT}}$ and $T_{\mathrm{SF}}$ is the sea floor temperature at depth $Z_{\mathrm{SF}}$. The values of gradient calculated using (3) are found to fall in the range of 10 to $30^{\circ} \mathrm{C} / \mathrm{km}$. A summary of values of geothermal gradients for the set of wells considered in the present work is provided in Table 5.

As can be noted in the map of Figure 2, most of well sites are located along the central rift zone of the Campos basin, with the data density being poor in the coastal zone and also in the eastern portion of the study area. A convenient means of improving data density in the coastal area is to consider geothermal gradients values reported in [10] for 22 sites in the state of Rio de Janeiro. The problem arising from poor data density in the eastern segment of the Campos basin has been minimized by considering estimates of geothermal gradients 


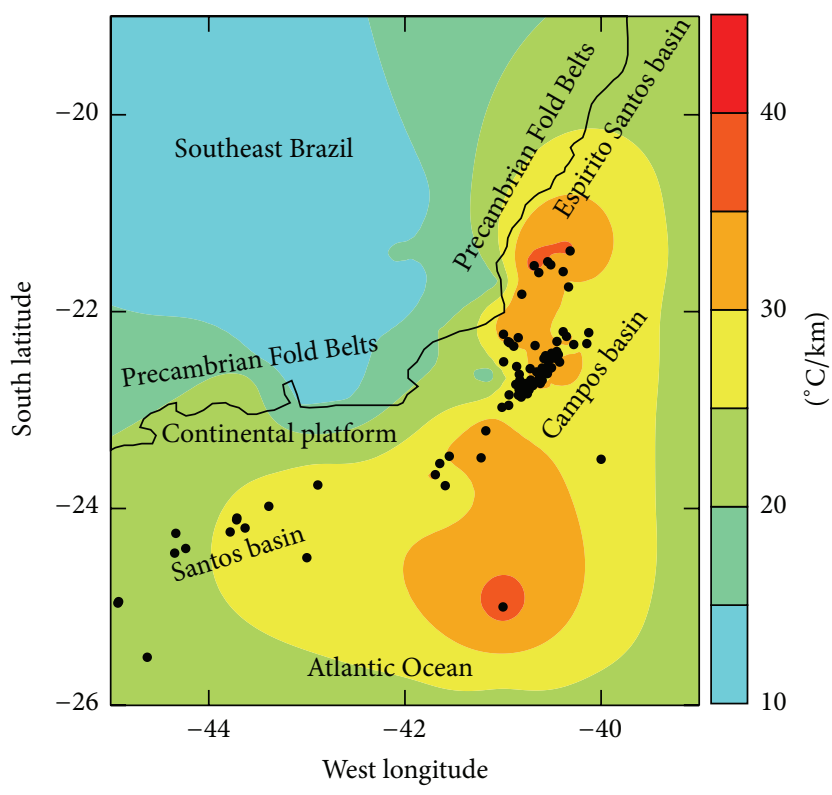

FIGURE 3: Map of geothermal gradients in the region comprising the Campos basin in the continental margin of southeast Brazil. The black dots are locations of geothermal gradient measurements. The position of the coastal zone is indicated by the dark curve. Also indicated are the locations of adjacent Santos and Espirito Santo basins.

for southwestern part of the Atlantic Ocean, reported in [11, 12, 39].

The regional distribution of gradient values is illustrated in the map of Figure 3. It reveals that the gradients are higher than $30^{\circ} \mathrm{C} / \mathrm{km}$ along a northeast-southwest trending arcuate belt. This belt of relatively high gradients is roughly coincident with the rift zone in the continental margin of southeast Brazil, identified in geologic studies. It is also coincident with the region of oil and gas fields, indicated in Figure 1.

3.4. Thermal Conductivity. The difficulties in obtaining suitable samples of deep sedimentary strata turned out to be the main problem in thermal conductivity studies of the Campos basin. Since core samples and cuttings from drilling operations of oil wells are rarely available for academic research, the availability of thermal property data is limited to results of isolated efforts. Marangoni and Hamza [40] carried out thermal conductivity measurements of ocean floor sediment samples in the coastal region of southeast Brazil. Gomes and Hamza [41] have carried out thermal conductivity measurements on samples of cuttings recovered in drilling operations of water wells in the state of Rio de Janeiro. More recently, del Rey and Zembruscki [42] reported results of thermal conductivity measurements on samples from the adjacent Espirito Santo basin. A summary of thermal conductivity values derived from results of these earlier studies is given in Table 3.

Viana [43] reported estimates of thermal conductivity for 33 sites in the Campos basin based on a procedure that

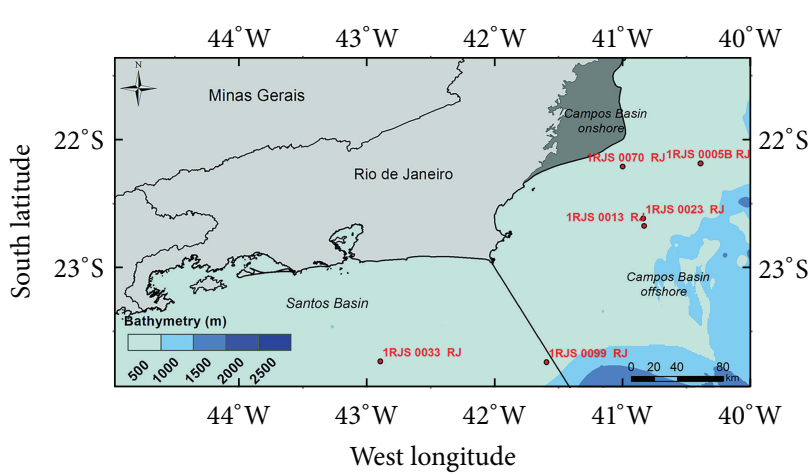

FIGURE 4: Locations of six wells with geophysical logs, employed for determination of thermal conductivity.

makes use of information on relative proportions of solid rock matrix and of the fluids occupying the pore spaces of samples collected during drilling operations. The procedure adopted makes use of literature values of thermal conductivity of the rock matrix and pore fluids (see, e.g., [44]) in deriving estimates of effective thermal conductivities.

In the present work, additional determinations of thermal conductivity were made making use of log data provided by the National Agency of Petroleum (ANP) for six wells in the Campos basin. In addition, lithologic descriptions of samples collected during drilling operations were also made available by ANP. The locations of these wells are indicated in the map of Figure 4.

The procedure for thermal conductivity determinations adopted in the present work is essentially the same as that adopted by Viana [43], with the exception that porosity values were derived from well log data. Thermal conductivity values $(k)$ of the fluid saturated medium with porosity $\phi$ were calculated using the relation proposed by Woodside and Messmer [45]:

$$
k(z)=k_{s}^{1-\phi(z)} k_{w}^{\phi(z)} .
$$

In (4), $k_{s}$ is the thermal conductivity of solid matrix and $k_{w}$ is that of the fluid in the pore space. As an illustrative example, we present in Figure 5 results obtained from analysis of lithologic descriptions of samples collected from well RJS-23. Note that overall distributions of thermal conductivity values are in the general range of 1 to $4 \mathrm{~W} / \mathrm{m} /{ }^{\circ} \mathrm{C}$. As expected, the rock formations rich in silt and shale fractions are characterized by relatively low values of thermal conductivity, while sections rich in carbonates and evaporates have relatively high values. A summary of the values of the main rock types obtained by this method is provided in Table 4 .

The determinations of thermal conductivity were also carried out using geophysical well log data provided by ANP. The logs provide vertical distributions of sonic velocity, gamma ray, bulk density, and electrical resistivity. Among these, logs of sonic velocity were found most useful for the present work. The procedure adopted here is based on a modified form of the empirical relation proposed by Houbolt 
TABLE 3: Thermal conductivity values reported in earlier studies. The names in brackets in the second column are corresponding formations in the adjacent Campos basin.

\begin{tabular}{|c|c|c|c|}
\hline Region & Layer/formation & Rock type & $\begin{array}{l}\text { Thermal conductivity } \\
(\mathrm{W} / \mathrm{m} / \mathrm{K})\end{array}$ \\
\hline Platform area [40] & Ocean floor & Sediments & $1.5-2.1$ \\
\hline \multirow{2}{*}{ Continental part of Campos basin [41] } & \multirow{2}{*}{ Drill cuttings } & Shaly sand & $2.2-3.5$ \\
\hline & & Sandy shale & $2.5-3.2$ \\
\hline \multirow{12}{*}{ Campos $([63,64])$ and Espirito Santo [42] basins } & \multirow{2}{*}{ Rio Doce (Emborê) } & Shale & 1.6 \\
\hline & & Sandstone & 1.9 \\
\hline & Caravelas (Ubatuba) & Carbonates & 2.3 \\
\hline & \multirow{2}{*}{ Urucutuca (Campos) } & Shale & 1.9 \\
\hline & & Sandstone & 2.7 \\
\hline & \multirow{3}{*}{ Barra Nova (Macaé) } & Shale & 1.7 \\
\hline & & Sandstone & 2.5 \\
\hline & & Carbonates & 3.0 \\
\hline & \multirow{4}{*}{ Mariricu (Lagoa Feia) } & Shale & 2.4 \\
\hline & & Sandstone & 2.8 \\
\hline & & Carbonates & 2.9 \\
\hline & & Anhydrite & 5.7 \\
\hline \multirow{2}{*}{ Basement [77] } & \multirow{2}{*}{ Precambrian } & Mafics & 2.1 \\
\hline & & Metamorphics & 3.9 \\
\hline
\end{tabular}

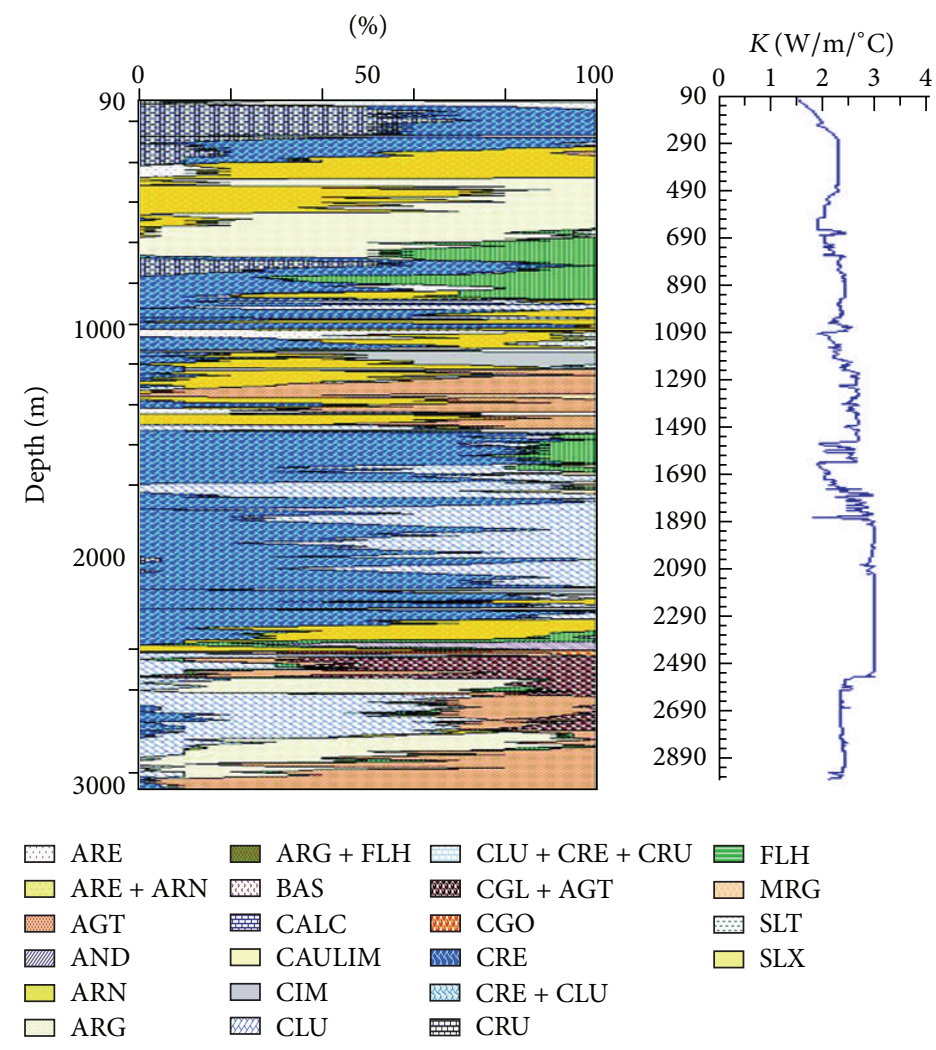

FIGURE 5: Lithologic sequences encountered in well RJS23 (left-hand part of the upper panel) and thermal conductivity values (right-hand part of the upper panel). The legend for lithologic sequences is indicated in the lower panel. The rock types identified are ARE: sand, ARN: sandstone, AGT: argillite, AND: anhydrite, ARG: clay, BAS: basalt, CALC: limestone, CAULIM: kaolin, CIM: cement, CLU: calcilutite, CGL+AGT: conglomerate with argillite, CGO: conglomerate, CRE: calcarenite, CRU: calcirudite, FLH: shale, MRG: marga, SLT: siltstone, and SLX: silex. 
TABLE 4: Mean thermal conductivities of sedimentary formations in the Campos basin, derived from lithologic descriptions of drill cuttings.

\begin{tabular}{lcc}
\hline Stratigraphic unit & Dominant lithology & $\begin{array}{c}\text { Thermal conductivity } \\
(\mathrm{W} / \mathrm{m} / \mathrm{K})\end{array}$ \\
\hline Emborê formation & Sandstones & $2.0 \pm 0.4$ \\
Mb. Grussaí & Carbonates & $1.9 \pm 0.3$ \\
Mb. Siri & Carbonates & $2.2 \pm 0.4$ \\
Macaé formation & Carbonates & $2.9 \pm 0.5$ \\
Mb. Ubatuba & Sandstones & $2.4 \pm 0.4$ \\
Mb. Carapebus & Sandstones & $2.5 \pm 0.5$ \\
Lagoa Feia & Shale (Coquina) & $2.8 \pm 0.6$ \\
formation & & \\
Cretaceous & Sandstones and shale & $2.3 \pm 0.5$ \\
sediments &
\end{tabular}

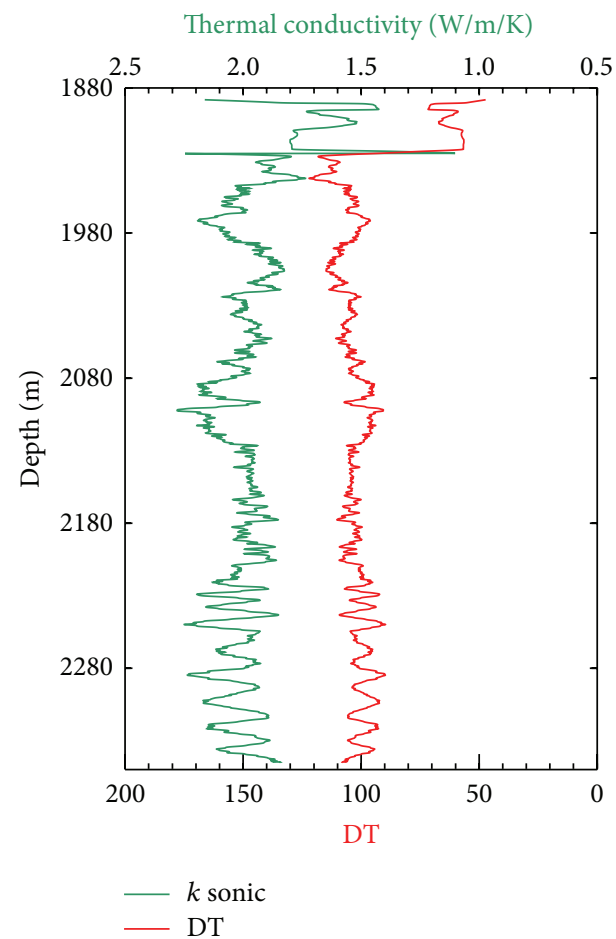

Figure 6: Illustration of the relation between transit time (DT) profiles (red curve) and thermal conductivity (green curve) derived from empirical relation [46], for depth interval from 1880 to $2300 \mathrm{~m}$ in well RJS-99.

and Wells [46] between sonic velocity $\left(V_{P}\right)$ and thermal conductivity of saturated medium $\left(k_{s}\right)$ :

$$
k_{s}=\frac{(d+a) V_{p}}{b(c+T)}
$$

where $a, b$, and $c$ are empirical constants, $T$ the temperature, and $d$ an off-set parameter specific to the particular sonic $\log$. The values of the off-set parameter need to be adjusted in order to obtain thermal conductivity values that are physically realistic and compatible with the range of values listed in Table 4. The numerical values of off-sets that provide best results have been found to be 33 for well RJS-33, 30.5 for well RJS-70, and 75 for well RJS-99. The values of temperature $T$ at depth $Z$ were derived from the relation

$$
T(Z)=T_{\mathrm{BHT}}-\Gamma\left(Z_{\mathrm{BHT}}-Z\right),
$$

in which $\Gamma$ is the value of the geothermal gradient. The sonic log of well RJS-99, presented in Figure 6, illustrates the inverse relation between transit time (which is the reciprocal of sonic velocity) and thermal conductivity. This procedure has been employed in determining vertical distributions of thermal conductivity for the set of six wells indicated in Figure 4 . The final results are presented in Figure 7.

3.5. Heat Flux. The procedure employed in calculating heat flow $(q)$ followed the practice set out in [47]. It makes use of the relation between temperatures at bottom-hole $\left(T_{\mathrm{BHT}}\right)$ and at sea floor $\left(T_{\mathrm{SF}}\right)$ :

$$
q=\frac{\left(T_{\mathrm{BHT}}-T_{\mathrm{SF}}\right)}{\sum_{i=1}^{N} R_{i} Z_{i}},
$$

where $N$ is the number of layers and $R_{i}$ is the thermal resistivity (inverse of thermal conductivity) of the $i$ th layer with thickness $Z_{i}$. The summation over $N$ layers allows determination of the cumulative thermal resistance up to the depth at which BHT measurement was carried out.

Heat flow values were calculated using (7) for 76 localities in the oceanic segment of the Campos basin. For the sites of six wells, indicated in Figure 4, thermal conductivity values derived from sonic logs were employed in calculating heat flow. For the sites of the remaining 70 wells, heat flow values were calculated using estimates of thermal conductivity reported in [43]. A summary of values of geothermal gradients, thermal conductivity, and heat flow for the set of wells considered in the present work is provided in Table 5.

As in the case of temperature gradients discussed earlier, the data density is poor in the coastal zone and also in the eastern portion of the Campos basin. Heat flow values reported in [10] for 22 sites in the state of Rio de Janeiro served as constraints in interpolation schemes used for deriving maps for areas adjacent to the coastal zone. Also, the undesirable effects of poor data density in the eastern segment of the Campos basin have been minimized by considering estimates of heat flow for the southwestern part of the Atlantic Ocean, reported in [11, 12, 39].

The regional distribution of heat flow values is illustrated in the map of Figure 8. It reveals the presence of a region with heat flow greater than $70 \mathrm{~mW} / \mathrm{m}^{2}$ in the northern part of the Campos basin. This zone of high heat flow has the shape of an arcuate belt, similar to the zone of anomalous geothermal gradients indicated in Figure 3. Its position is closer to the continent in the northern part, near the border with Espirito Santo basin. In the south, at the border with Santos basin, it is nearly $200 \mathrm{~km}$ away from the coast. Note that the width of the high heat flow belt is in the range of 100 to $150 \mathrm{~km}$. The nature of tectonic processes responsible for the origin of the anomalous heat flux is unknown. But it certainly represents 

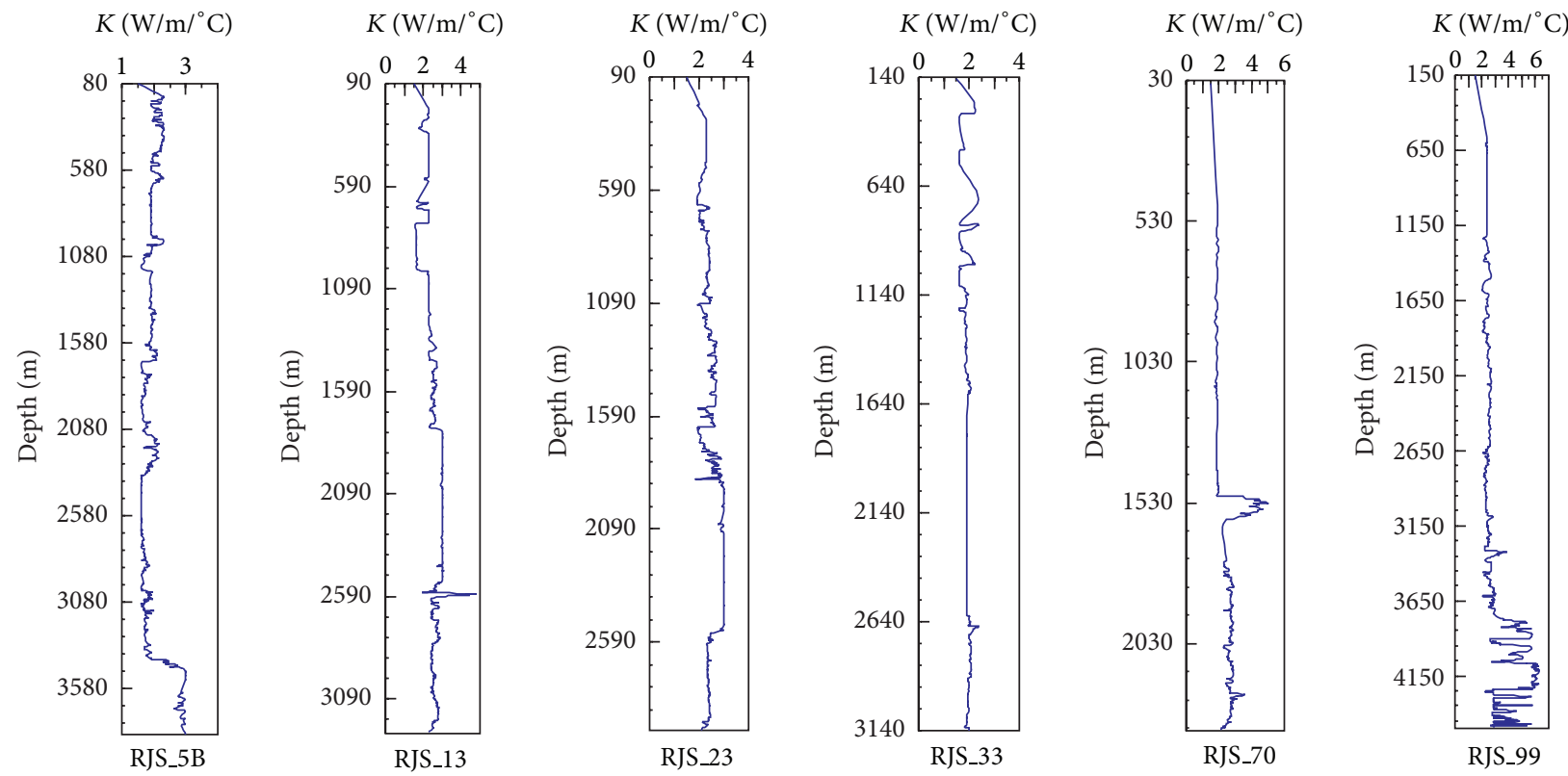

FIGURE 7: Vertical distributions of thermal conductivity, derived from lithologic descriptions of samples collected during drilling operations, at sites of six wells indicated in Figure 4.

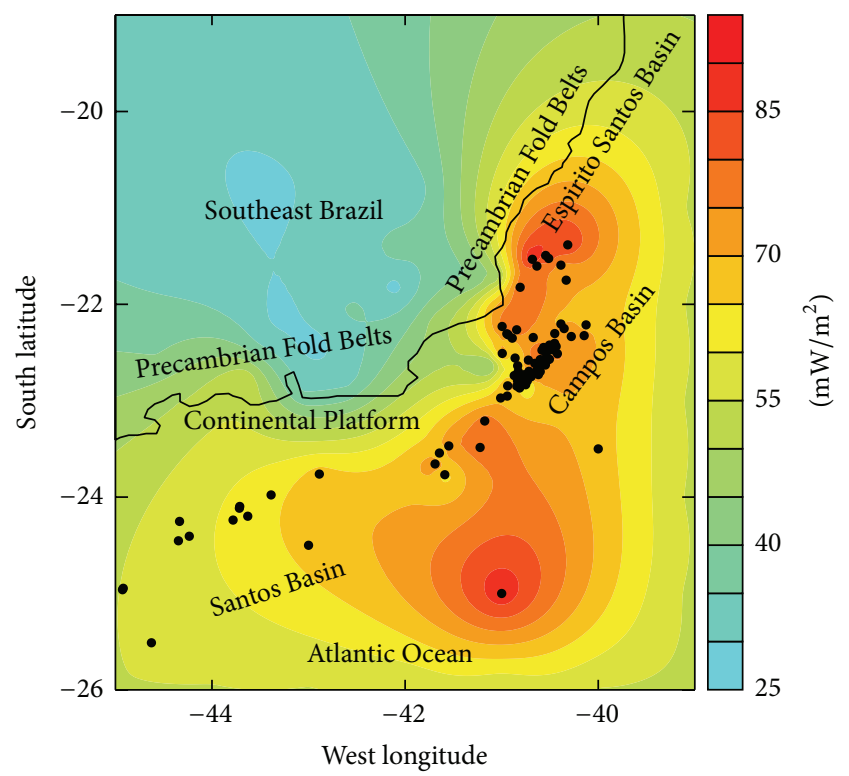

FIGURE 8: Map of terrestrial heat flow of the region comprising the Campos basin in the continental margin of southeast Brazil. The black dots are locations of geothermal measurements. The position of the coastal zone is indicated by the dark curve. Also indicated are the locations of adjacent Santos and Espirito Santo basins.

a relatively recent thermal reactivation episode, unrelated to previous magmatic events. In fact, the relatively narrow width of the anomaly is an indication that the heat source is located at relatively shallow crustal depths and the time elapsed is no more than $10 \mathrm{Ma}$.
3.6. Vertical Distribution of Temperatures. Vertical distributions of temperatures at the sites of six wells, referred to in Figure 4, have been calculated making use of data on bottomhole temperatures, thermal conductivity, and heat flow. The relation used is

$$
T(z)=T_{0}+\int_{0}^{z} q R(z) d z
$$

where $T_{0}$ is the sea floor temperature, $Z$ the thickness of the layer under consideration, $q$ the heat flux, and $R$ the thermal resistance of the layer. Vertical distributions of temperatures, calculated using (8), are illustrated in Figure 9 for the set of six wells indicated in Figure 4. The calculated temperature profiles are nearly linear, implying that most of the heat transfer takes place by conduction. There are indications that departures from linearity are related to thermal property variations associated with changes in lithologic sequences.

Nevertheless, vertical distribution of BHT data for the remaining wells reveals the presence of a curvature that is convex towards the depth axis. In the absence of thermal refraction effects, possible mechanisms that can produce such curvatures are either systematic increase in thermal conductivity with depth or heat transfer associated with upflow of fluids. Large-scale variations in the sea floor temperatures can also lead to curvatures in subsurface temperature profiles but this mechanism seems unlikely. Vertical variations of thermal conductivity encountered in the wells (see Figure 7) rule out the possibility of systematic increase with depth. This leaves advection heat transfer by upflow of fluids as the most likely mechanism.

At this point, it is convenient to examine the thermal effects of fluid flow in permeable media. Lu and Ge [48] derived a solution for the problem of heat transfer in a 


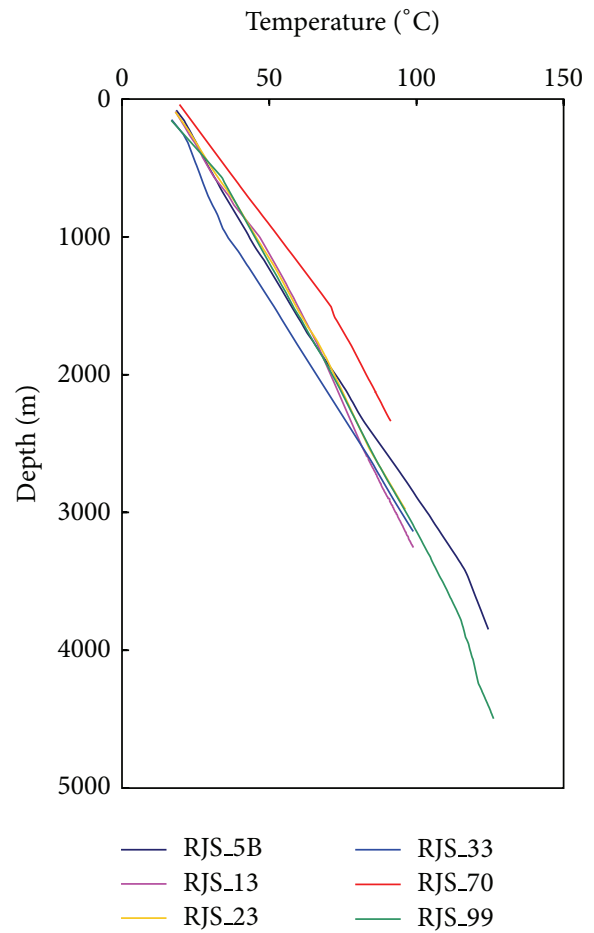

FIGURE 9: Vertical distribution of temperatures at sites of six wells, indicated in the map of Figure 4.

permeable medium, allowing for the effects of advective fluid flows in both horizontal and vertical directions. For a layer with thickness $L$, in which fluid flow takes place with velocities $v_{x}$ and $v_{z}$ in the $x$ and $z$ directions, respectively, the solution for temperature $T$ at depth $z$ within the medium may be expressed as

$$
\begin{aligned}
& \frac{T-T_{0}}{T_{L}-T_{0}} \\
& \quad=\left\{\frac{\exp [\beta(z / L)]-1}{\exp (\beta)-1}+\frac{\alpha \gamma}{\beta \eta}\left[\frac{\exp [\beta(z / L)]-1}{\exp (\beta)-1}-\frac{z}{L}\right]\right\} .
\end{aligned}
$$

In (9), $T_{0}$ and $T_{L}$ refer, respectively, to temperatures at the top and bottom boundaries of the flow domain. The terms $\alpha(\alpha=$ $\left.c_{w} \rho_{w} v_{x} L / \kappa\right)$ and $\beta\left(\beta=c_{w} \rho_{w} v_{z} L / \kappa\right)$ represent dimensionless Peclet numbers, and the terms $\eta$ and $\gamma$ are, respectively, the vertical and horizontal temperature gradients. Note that, in the absence of fluid movement in the horizontal direction (and/or horizontal temperature gradient), (9) is simplified to the case of vertical flow discussed in [49]. The left-hand side of this equation represents the dimensionless temperature $(\theta)$. Its variation with depth $z$ allows the use of curvematching methods for determination of the flow parameter $\beta$ and the quantity $\delta(=\alpha \gamma / \beta \eta)$. These results in turn may be used for determination of the velocity components, as pointed out by [50] and more recently by [51].

An example of the curve-matching procedure is illustrated in Figure 10 for BHT data for a selected set of ten wells located at sites of turbidity deposits. In this case, the vertical

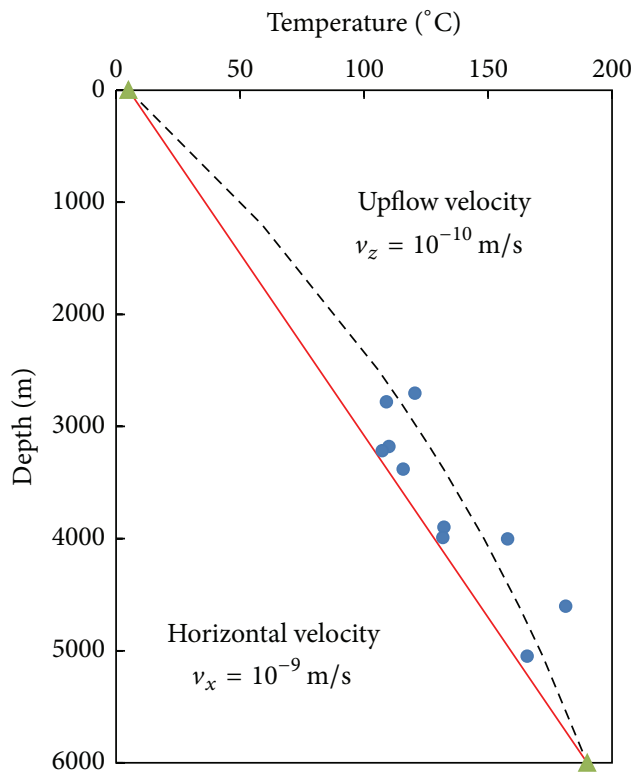

FIGURE 10: Illustration of nonlinearity in temperature variation with depth in the Campos basin. The dashed curve is the fit to the observational data based on the model of $\mathrm{Lu}$ and Ge [48].

and horizontal velocities of fluid flow are found to be of the order of $10^{-10}$ and of $10^{-9} \mathrm{~m} / \mathrm{s}$, respectively. The red line in this figure refers to the case where no flow takes place. It is possible that hydraulic head of groundwater trapped in turbidity deposits provides favorable conditions for advective upflow of fluids in the central rift zone of this basin.

\section{Subsidence History of the Campos Basin}

The sequence of tectonic events that gave rise to formation of the Campos basin has been the object of a number of investigations over the last few decades. Most of them are focused on the geological characteristics of events associated with early continental rift (e.g., [52-56]) and influence of hot-spot activities in the South Atlantic (e.g., [57, 58]). Thermomechanical aspects of basin evolution have also been considered in several studies (e.g., [59-61]), but again with emphasis on geological aspects. Only recently analysis of geothermal data has been taken up as a complementary tool in model studies of subsidence of the Campos basin [6264]. In the present work, updated data sets on temperature gradients and heat flow are employed along with available information on lithologic sequences and geophysical logs of deep oil wells in obtaining better insights into the thermotectonic evolution of the Campos basin.

It is customary in model studies of subsidence history to start off with reconstruction of depositional sequences, the results of which are employed subsequently in determining paleothermal conditions of sedimentary strata. This standard approach has also been adopted in the present work where attention is focused initially on determining the characteristics of subsidence driven by sediment loads. Results of this initial stage are employed later in model simulations 


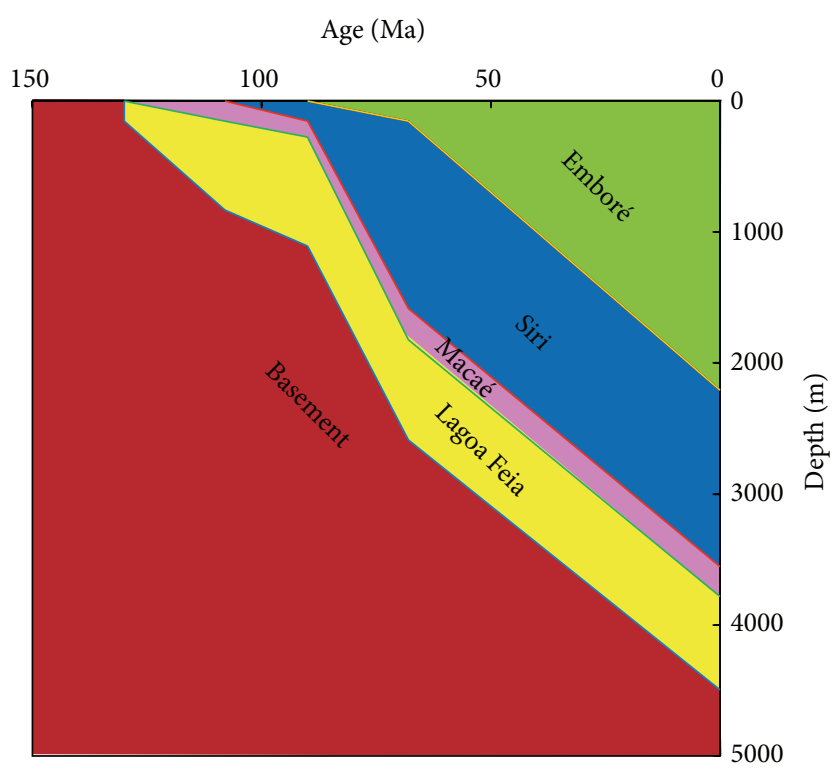

FIGURE 11: Example of backstripping procedure applied to lithologic sequences in well RJS-99.

for determining the characteristics of deep seated thermal processes.

4.1. Sediment-Loaded Subsidence. It is common practice in the relevant literature (e.g., [65]) to employ methods of backstripping in analysis of geohistory of sediment-loaded subsidence. The standard procedure involves examining the effects of sequential removal of sedimentary strata within the framework of isostatic response to unloading. The ensuing changes in thickness, density, and porosity values of sedimentary layers are then calculated using appropriate relations for sediment decompaction (e.g., [66]). In the present work, available information on lithologic sequences and geophysical well logs was employed in determining subsidence history at sites of the six wells, indicated in Figure 4. An illustrative example of the backstripping procedure is presented in Figure 11, for the site of the well RJS-99. In this figure, the sequential line segments indicate the nature of age-depth relations during the depositional history of individual formations. The point of intersection of the final line segment with the vertical depth axis indicates the present thickness of the formation, while the breaks in the lines indicate changes in the depositional sequences. The colored areas in this figure indicate the age-depth relations of the main sedimentary formations (Lagoa Feia, Siri, Macaé, and Emboré) during the evolutionary history of subsidence. Note that the thicknesses of formations decrease with depth due to compaction. The degree of compaction is relatively large for shale rich formations. For example, the original thickness of shale rich Lagoa Feia formation is 831 meters at the depositional age of $110 \mathrm{Ma}$, while the present thickness is 714 meters, a reduction of approximately $14 \%$. Similar rates are also found for Siri formation.
A summary of the results obtained in applying the backstripping procedure to data sets derived from drill records is provided in Table 6 , for the six wells indicated in Figure 4. It includes values calculated for the thicknesses of the formations and their respective porosities, at the main stages of evolution of the Campos basin. Note that, for any particular formation, the thicknesses and porosities decrease with elapsed time. However, the rates of changes vary from one well site to another. In general, shale rich formations were found to have relatively high compaction rates.

4.2. Thermal Subsidence. According to extensional models of basin evolution (e.g., [67]), stretching processes taking place in the crust and upper mantle play significant roles in the evolutionary histories of sedimentary basins. In deriving estimates of deep seated stretching, the usual practice is to start off with determinations of thermal subsidence, which is the subsidence discounted for the effects of sediment loading. It is calculated using the relation described in [67] for elevation $(e)$ :

$$
e(t)=\left(\frac{a \rho_{m} \alpha T_{m}}{\rho_{m}-\rho_{w}}\right) \frac{4}{\pi^{2}}\left[\left(\frac{\beta}{\pi} \operatorname{sen} \frac{\pi}{\beta}\right) e^{-t / \tau}\right],
$$

where $a$ is the thickness of the lithosphere, $\rho_{m}$ the mantle density, $\rho_{w}$ the density of sea water, $\alpha$ the linear thermal expansion coefficient, $T_{m}$ the temperature of the mantle, $\beta$ the stretching factor, $t$ the time elapsed after the stretching event, and $\tau$ the thermal time constant of the lithosphere. This last parameter is defined in [67] as

$$
\tau=\frac{a^{2}}{\pi^{2} \kappa}
$$

in which $\kappa$ is the thermal diffusivity of the lithosphere. The thermal subsidence is the difference between elevation $(e)$ and that above the datum for thermal equilibrium. The values of the parameters given in (10) and (11) are listed in Table 7.

In the model proposed by [67], the stretching factor $(\beta)$, which determines the thermal subsidence, is assumed to be constant at all depths in the lithosphere. Royden and Keen [68] proposed a model in which the rate of crustal stretching $(\delta)$ is different from that of subcrustal lithosphere $(\beta)$. In this latter case, the relation for thermal subsidence is derived from the relation

$$
\begin{aligned}
e(t)= & \left(\frac{2 a \rho_{m} \alpha T_{m}}{\left(\rho_{m}-\rho_{w}\right) \pi}\right) \frac{2}{\pi^{2}} \\
& \times\left[(\beta-\delta) \sin \left(\frac{\pi T_{m}}{a \beta}\right)+\delta \sin \left(\frac{\pi}{\gamma}\right) e^{-t / \tau}\right] .
\end{aligned}
$$

These two models (designated hereafter as constant stretching (CS) and variable stretching (VS), resp.) were employed in studies of thermal subsidence in the present work. Note that, for $\beta>\delta$, the value of thermal subsidence calculated for the VS model is always smaller than that for the CS model.

An illustrative example is presented in Figure 12 for thermal subsidence curves at the site of well RJS-23, calculated on 
TABLE 5: Summary of geothermal gradient $(\Gamma)$, thermal conductivity $(\lambda)$, and heat flow $(q)$ values for 76 wells in the Campos basin. Error vales $(\sigma)$ refer to uncertainties in the methods used for determination of the relevant parameters.

\begin{tabular}{|c|c|c|c|c|c|c|}
\hline \multirow{2}{*}{ Well ID } & \multicolumn{2}{|c|}{$\Gamma\left({ }^{\circ} \mathrm{C} / \mathrm{km}\right)$} & \multicolumn{2}{|c|}{$\lambda(\mathrm{w} / \mathrm{m} / \mathrm{K})$} & \multicolumn{2}{|c|}{$q\left(\mathrm{~mW} / \mathrm{m}^{2}\right)$} \\
\hline & Mean & $\sigma_{\Gamma}$ & Mean & $\sigma_{\lambda}$ & Mean & $\sigma_{q}$ \\
\hline 1-RJS-5B & 31.8 & 2.2 & 2.1 & 0.2 & 66.7 & 6.7 \\
\hline 1-RJS-13 & 31.3 & 2.2 & 2.5 & 0.2 & 79.1 & 7.9 \\
\hline 1-RJS-23 & 31.4 & 2.2 & 2.5 & 0.2 & 76.9 & 7.7 \\
\hline 1-RJS-26 & 29.2 & 2.0 & 2.6 & 0.2 & 75.8 & 7.6 \\
\hline 1-RJS-27 & 36.8 & 2.6 & 3.0 & 0.2 & 110.4 & 11.0 \\
\hline 1-RJS-28A & 33.8 & 2.4 & 2.5 & 0.2 & 84.4 & 8.4 \\
\hline 1-RJS-32 & 35.6 & 2.5 & 2.5 & 0.2 & 89.1 & 8.9 \\
\hline 1-RJS-33 & 31.8 & 2.2 & 1.9 & 0.2 & 60.2 & 6.0 \\
\hline 1-RJS-36 & 32.2 & 2.3 & 2.9 & 0.2 & 93.5 & 9.3 \\
\hline 1-RJS-38 & 35.5 & 2.5 & 2.7 & 0.2 & 95.8 & 9.6 \\
\hline 1-RJS-41 & 33.9 & 2.4 & 2.8 & 0.2 & 94.8 & 9.5 \\
\hline 4-RJS-42 & 32.5 & 2.3 & 2.5 & 0.2 & 81.2 & 8.1 \\
\hline 1-RJS-43 & 30.2 & 2.1 & 2.3 & 0.2 & 69.6 & 7.0 \\
\hline 1-RJS-44 & 37.9 & 2.7 & 2.4 & 0.2 & 91.0 & 9.1 \\
\hline 1-RJS-45 & 33.4 & 2.3 & 2.5 & 0.2 & 83.4 & 8.3 \\
\hline 1-RJS-46 & 32.3 & 2.3 & 2.9 & 0.2 & 93.6 & 9.4 \\
\hline 1-RJS-47E & 34.2 & 2.4 & 2.8 & 0.2 & 95.8 & 9.6 \\
\hline 1-RJS-48 & 33.6 & 2.4 & 2.5 & 0.2 & 84.1 & 8.4 \\
\hline 1-RJS-49 & 30.9 & 2.2 & 2.7 & 0.2 & 83.6 & 8.4 \\
\hline 1-RJS-50 & 37.2 & 2.6 & 2.5 & 0.2 & 92.9 & 9.3 \\
\hline 1-RJS-52 & 34.4 & 2.4 & 2.3 & 0.2 & 79.1 & 7.9 \\
\hline 1-RJS-53 & 33.6 & 2.4 & 2.5 & 0.2 & 84.1 & 8.4 \\
\hline 1-RJS-54 & 35.0 & 2.4 & 2.4 & 0.2 & 84.0 & 8.4 \\
\hline 4-RJS-55 & 28.3 & 2.0 & 2.5 & 0.2 & 70.8 & 7.1 \\
\hline 1-RJS-56 & 33.0 & 2.3 & 2.8 & 0.2 & 92.4 & 9.2 \\
\hline 1-RJS-57 & 37.9 & 2.7 & 2.5 & 0.2 & 94.6 & 9.5 \\
\hline 1-RJS-58 & 35.3 & 2.5 & 2.2 & 0.2 & 77.6 & 7.8 \\
\hline 3-RJS-59 & 34.7 & 2.4 & 2.5 & 0.2 & 86.6 & 8.7 \\
\hline 1-RJS-60 & 33.3 & 2.3 & 2.3 & 0.2 & 76.7 & 7.7 \\
\hline 4-RJS-62A & 30.6 & 2.1 & 2.5 & 0.2 & 76.5 & 7.7 \\
\hline 1-RJS-63A & 28.3 & 2.0 & 2.8 & 0.2 & 79.2 & 7.9 \\
\hline 1-RJS-64A & 28.8 & 2.0 & 2.9 & 0.2 & 83.6 & 8.4 \\
\hline 1-RJS-65 & 31.5 & 2.2 & 2.5 & 0.2 & 78.9 & 7.9 \\
\hline 1-RJS-66 & 33.4 & 2.3 & 2.6 & 0.2 & 86.9 & 8.7 \\
\hline 1-RJS-68 & 32.3 & 2.3 & 2.5 & 0.2 & 80.8 & 8.1 \\
\hline 1-RJS-69 & 33.7 & 2.4 & 2.4 & 0.2 & 80.9 & 8.1 \\
\hline 1-RJS-70 & 35.2 & 2.5 & 2.4 & 0.2 & 82.7 & 8.3 \\
\hline 1-RJS-71 & 33.1 & 2.3 & 2.5 & 0.2 & 82.7 & 8.3 \\
\hline 1-RJS-73 & 32.2 & 2.3 & 2.2 & 0.2 & 70.8 & 7.1 \\
\hline 1-RJS-74 & 34.3 & 2.4 & 2.3 & 0.2 & 78.9 & 7.9 \\
\hline 1-RJS-75 & 34.0 & 2.4 & 2.9 & 0.2 & 98.5 & 9.8 \\
\hline 1-RJS-76 & 30.9 & 2.2 & 2.2 & 0.2 & 68.0 & 6.8 \\
\hline 1-RJS-78 & 33.7 & 2.4 & 2.5 & 0.2 & 84.2 & 8.4 \\
\hline 1-RJS-79 & 38.0 & 2.7 & 2.8 & 0.2 & 106.4 & 10.6 \\
\hline 3-RJS-80 & 36.0 & 2.5 & 2.5 & 0.2 & 90.0 & 9.0 \\
\hline 1-RJS-82 & 36.9 & 2.6 & 2.4 & 0.2 & 88.5 & 8.9 \\
\hline 1-RJS-83 & 32.7 & 2.3 & 2.3 & 0.2 & 75.1 & 7.5 \\
\hline
\end{tabular}

TABLE 5: Continued.

\begin{tabular}{lcccccc}
\hline \multirow{2}{*}{ Well ID } & \multicolumn{2}{c}{$\Gamma\left({ }^{\circ} \mathrm{C} / \mathrm{km}\right)$} & \multicolumn{2}{c}{$\lambda(\mathrm{w} / \mathrm{m} / \mathrm{K})$} & \multicolumn{2}{c}{$q\left(\mathrm{~mW} / \mathrm{m}^{2}\right)$} \\
& Mean & $\sigma_{\Gamma}$ & Mean & $\sigma_{\lambda}$ & Mean & $\sigma_{q}$ \\
\hline 1-RJS-84 & 35.1 & 2.5 & 2.5 & 0.2 & 87.9 & 8.8 \\
1-RJS-85 & 33.8 & 2.4 & 2.2 & 0.2 & 74.4 & 7.4 \\
1-RJS-88 & 35.0 & 2.5 & 2.5 & 0.2 & 87.5 & 8.8 \\
1-RJS-89 & 34.0 & 2.4 & 2.4 & 0.2 & 81.5 & 8.2 \\
1-RJS-90 & 33.3 & 2.3 & 2.5 & 0.2 & 83.3 & 8.3 \\
1-RJS-91 & 36.0 & 2.5 & 2.6 & 0.2 & 93.7 & 9.4 \\
1-RJS-92 & 32.1 & 2.2 & 2.7 & 0.2 & 86.6 & 8.7 \\
1-RJS-93 & 33.2 & 2.3 & 2.5 & 0.2 & 83.0 & 8.3 \\
1-RJS-94 & 41.7 & 2.9 & 2.8 & 0.2 & 116.8 & 11.7 \\
1-RJS-95 & 33.6 & 2.3 & 2.2 & 0.2 & 73.8 & 7.4 \\
1-RJS-96A & 39.0 & 2.7 & 2.2 & 0.2 & 85.9 & 8.6 \\
1-RJS-97C & 33.3 & 2.3 & 2.3 & 0.2 & 76.5 & 7.7 \\
1-RJS-99 & 29.4 & 2.1 & 2.1 & 0.2 & 61.8 & 6.2 \\
1-RJS-100 & 30.8 & 2.2 & 2.5 & 0.2 & 76.9 & 7.7 \\
1-RJS-101 & 40.1 & 2.8 & 2.1 & 0.2 & 84.1 & 8.4 \\
1-RJS-102A & 30.4 & 2.1 & 2.1 & 0.2 & 63.8 & 6.4 \\
1-RJS-105 & 34.6 & 2.4 & 2.6 & 0.2 & 90.0 & 9.0 \\
1-RJS-106 & 38.7 & 2.7 & 2.5 & 0.2 & 96.8 & 9.7 \\
1-RJS-107 & 34.9 & 2.4 & 2.7 & 0.2 & 94.2 & 9.4 \\
1-RJS-108 & 32.3 & 2.3 & 2.1 & 0.2 & 67.8 & 6.8 \\
1-RJS-111 & 34.0 & 2.4 & 2.5 & 0.2 & 84.9 & 8.5 \\
1-RJS-113 & 31.3 & 2.2 & 2.6 & 0.2 & 81.4 & 8.1 \\
1-RJS-114 & 26.9 & 1.9 & 2.5 & 0.2 & 67.2 & 6.7 \\
1-RJS-115 & 26.7 & 1.9 & 2.4 & 0.2 & 64.1 & 6.4 \\
1-RJS-116 & 32.4 & 2.3 & 2.5 & 0.2 & 80.9 & 8.1 \\
1-RJS-117 & 28.4 & 2.0 & 2.2 & 0.2 & 62.4 & 6.2 \\
3-RJS-120 & 32.9 & 2.3 & 2.5 & 0.2 & 82.3 & 8.2 \\
4-RJS-121 & 30.7 & 2.1 & 2.3 & 0.2 & 70.6 & 7.1 \\
1-RJS-125 & 32.3 & 2.3 & 2.5 & 0.2 & 80.8 & 8.1 \\
\hline
\end{tabular}

the basis of the CS and VS models. In this figure, the curve in green color represents the thermal subsidence derived for the VS model, while that in red color represents the subsidence for the CS model. The subsidence values for the CS model are in general similar to those of the VS model. However, thermal subsidence values derived from CS model are slightly higher than those for the VS model, a consequence of the fact that in the VS model the values of crustal stretching are systematically lower than those of the subcrustal layer. The curve in blue color represents the sediment-loaded subsidence. As expected, the difference between sedimentloaded and thermal subsidence increases with elapsed time. Another notable feature in Figure 12 is the indication of relatively high values of extension during the initial periods.

A summary of the stretching factors derived for the sites of six wells of the Campos basin, indicated in Figure 4, is presented in Table 8. It is important to point out that the values of elapsed time in the second column are approximate, derived from [69]. In general, the results obtained point to values in the range of 1.1 to 1.6 for the CS model. For the VS model, the stretching factors for the crust are found to 
TABLE 6: Evolutionary changes in thicknesses and porosities of sedimentary formations at six sites in the Campos basin, determined from results of the backstripping process.

\begin{tabular}{|c|c|c|c|c|c|c|c|c|c|}
\hline \multirow{2}{*}{ Well ID } & \multirow{2}{*}{ Formation } & \multicolumn{4}{|c|}{ Thickness $(\mathrm{m})$ at elapsed time } & \multicolumn{4}{|c|}{ Porosity (\%) at elapsed time } \\
\hline & & $0 \mathrm{Ma}$ & $68 \mathrm{Ma}$ & $90 \mathrm{Ma}$ & $108 \mathrm{Ma}$ & $0 \mathrm{Ma}$ & $68 \mathrm{Ma}$ & $90 \mathrm{Ma}$ & $108 \mathrm{Ma}$ \\
\hline \multirow{2}{*}{ RJS-5b } & Emborê & 3135 & & & & 20 & & & \\
\hline & Cretaceous & 714 & 886 & & & 16 & 32 & & \\
\hline \multirow{4}{*}{ RJS-13 } & Emborê & 936 & & & & 28 & & & \\
\hline & Mb. Siri & 759 & 854 & & & 21 & 30 & & \\
\hline & Macaé & 801 & 845 & 903 & & 14 & 19 & 24 & \\
\hline & Lagoa Feia & 669 & 698 & 736 & 800 & 13 & 16 & 21 & 27 \\
\hline \multirow{4}{*}{ RJS-23 } & Emborê & 972 & & & & 28 & & & \\
\hline & Mb. Siri & 698 & 769 & & & 21 & 31 & & \\
\hline & Macaé & 808 & 831 & 867 & & 26 & 29 & 32 & \\
\hline & Lagoa Feia & 426 & 448 & 471 & 550 & 14 & 18 & 22 & 28 \\
\hline \multirow{3}{*}{ RJS-33 } & Emborê & 793 & & & & 30 & & & \\
\hline & Mb. Siri & 351 & 397 & & & 25 & 34 & & \\
\hline & Lagoa Feia & 1845 & 1981 & & 2062 & 16 & 21 & & 25 \\
\hline \multirow{2}{*}{ RJS-70 } & Emborê & 1470 & & & & 28 & & & \\
\hline & Lagoa Feia & 831 & & & 929 & 17 & & & 26 \\
\hline \multirow{4}{*}{ RJS-99 } & Emborê & 2054 & & & & 22 & & & \\
\hline & Mb. Siri & 1347 & 1586 & & & 12 & 26 & & \\
\hline & Macaé & 228 & 237 & 276 & & 11 & 20 & 31 & \\
\hline & Lagoa Feia & 714 & 763 & 830 & 831 & 10 & 15 & 22 & 24 \\
\hline
\end{tabular}

TABLE 7: Values of parameters used in models of backstripping and thermal subsidence.

\begin{tabular}{lccc}
\hline Parameter & Description & Value & Unit \\
\hline$\rho_{w}$ & Water density & 1 & $\mathrm{~g} / \mathrm{cm}^{3}$ \\
$\rho_{m}$ & Mantle density & 3.3 & $\mathrm{~g} / \mathrm{cm}^{3}$ \\
$\rho_{c}$ & Crustal density & 2.8 & $\mathrm{~g} / \mathrm{cm}^{3}$ \\
$a$ & Initial thickness of lithosphere & 125 & $\mathrm{~km}$ \\
$t_{c}$ & Initial thickness of the crust & 34 & $\mathrm{~km}$ \\
$\alpha$ & Linear thermal expansion coefficient & $3.3 \times 10^{-5}$ & 62.8 \\
$\tau$ & Time constant of the lithosphere & 4 & $\mathrm{Ma}$ \\
$\lambda$ & Thermal conductivity of the lithosphere & 0.56 & $\mathrm{~W} / \mathrm{m} / \mathrm{K}$ \\
$k_{w}$ & Thermal conductivity of water & 1333 & $\mathrm{~W} / \mathrm{m} / \mathrm{K}$ \\
$T_{l}$ & Temperature at the base of the lithosphere & $8 \times 10^{-7}$ \\
$\kappa$ & Thermal diffusivity of the lithosphere & ${ }^{\circ} \mathrm{C}$ \\
\hline
\end{tabular}

fall in the range of 1.1 to 1.7 , while those for the subcrustal lithosphere fall in the range of 1.3 to 2 . In the case of well RJS-5B there are no significant differences between the values of $\delta$ and $\beta$. On the other hand, values of $\delta$ are systematically lower than those of $\beta$ for data sets of wells RJS-13, RJS-23, RJS-33, and RJS-70. The results also reveal that the values of the parameters $\delta$ and $\beta$ are different for the main periods of stretching. Note that the differences in the values of $\delta$ and $\beta$ can lead to significant differences in the evolutionary history.

4.3. Paleoheat Flux. According to the extensional models, the stretching factors derived from thermal subsidence analysis may be employed in determination of heat flow during the evolutionary history of the basin. The relation for variation of heat flow $\left(q_{p}\right)$ during the period following the stretching episode is [67]

$$
q_{p}(t)=\frac{\lambda T_{m}}{a}\left\{1+2 \sum_{n=1}^{\infty}\left(\frac{\beta}{n \pi} \operatorname{sen} \frac{n \pi}{\beta}\right) e^{-n^{2}(t / \tau)}\right\},
$$

where $\lambda$ is the thermal conductivity of basement rocks, $a$ the thickness of the lithosphere, $\beta$ the stretching factor, $t$ the time elapsed after the initial stretching event, $\tau$ the thermal time constant of the lithosphere, and $T_{m}$ its basal temperature.

Paleoheat flow values may also be calculated using the variable stretching model. In this case, the relation for heat flux is

$$
q_{p}(t)=\frac{\lambda T_{1}}{a}\left\{1+\sum_{n=1}^{\infty}\left(2 x_{n}\right) e^{-n^{2}(t / \tau)}\right\}
$$


TABLE 8: Stretching parameters calculated for the sites of six wells, indicated in Figure 4. The error values refer to uncertainties in estimates of model fits.

\begin{tabular}{|c|c|c|c|c|}
\hline \multirow{3}{*}{ Well ID } & \multirow{3}{*}{ Elapsed time $(\mathrm{Ma})$} & \multicolumn{3}{|c|}{ Extensional model } \\
\hline & & \multirow{2}{*}{$\begin{array}{l}\text { Constant stretching }(\mathrm{CS}) \\
\text { Crust and subcrust }(\beta)\end{array}$} & \multicolumn{2}{|c|}{ Variable stretching (VS) } \\
\hline & & & Subcrustal $(\beta)$ & Crustal $(\delta)$ \\
\hline \multirow{2}{*}{ RJS_5B } & $0-60$ & $1.1 \pm 0.1$ & $2 \pm 0.2$ & $1.1 \pm 0.1$ \\
\hline & $60-130$ & $1.3 \pm 0.1$ & $1.6 \pm 0.2$ & $1.3 \pm 0.1$ \\
\hline \multirow{3}{*}{ RJS_13 } & $0-40$ & $1.6 \pm 0.2$ & $2 \pm 0.2$ & $1.5 \pm 0.1$ \\
\hline & $40-60$ & $1.4 \pm 0.2$ & $2 \pm 0.2$ & $1.3 \pm 0.1$ \\
\hline & $60-130$ & $1.2 \pm 0.1$ & $1.5 \pm 0.1$ & $1.2 \pm 0.1$ \\
\hline \multirow{3}{*}{ RJS_23 } & $0-40$ & $1.6 \pm 0.2$ & $1.6 \pm 0.2$ & $1.5 \pm 0.1$ \\
\hline & $40-60$ & $1.4 \pm 0.1$ & $1.6 \pm 0.2$ & $1.4 \pm 0.1$ \\
\hline & $60-130$ & $1.2 \pm 0.1$ & $1.5 \pm 0.2$ & $1.2 \pm 0.1$ \\
\hline \multirow{3}{*}{ RJS_33 } & $0-60$ & $1.6 \pm 0.2$ & $1.6 \pm 0.2$ & $1.5 \pm 0.1$ \\
\hline & $60-100$ & $1.4 \pm 0.1$ & $1.6 \pm 0.2$ & $1.3 \pm 0.1$ \\
\hline & $100-130$ & $1.2 \pm 0.1$ & $1.3 \pm 0.1$ & $1.1 \pm 0.1$ \\
\hline \multirow{3}{*}{ RJS_70 } & $0-22$ & $1.4 \pm 0.1$ & $1.6 \pm 0.2$ & $1.3 \pm 0.1$ \\
\hline & $22-60$ & $1.3 \pm 0.1$ & $1.5 \pm 0.2$ & $1.1 \pm 0.1$ \\
\hline & 60-130 & $1.2 \pm 0.1$ & $1.3 \pm 0.1$ & $1.1 \pm 0.1$ \\
\hline \multirow{3}{*}{ RJS_99 } & $0-40$ & $1.6 \pm 0.2$ & $2 \pm 0.2$ & $1.7 \pm 0.2$ \\
\hline & $40-60$ & $1.5 \pm 0.2$ & $2 \pm 0.2$ & $1.5 \pm 0.1$ \\
\hline & $60-130$ & $1.4 \pm 0.1$ & $1.7 \pm 0.2$ & $1.1 \pm 0.1$ \\
\hline
\end{tabular}

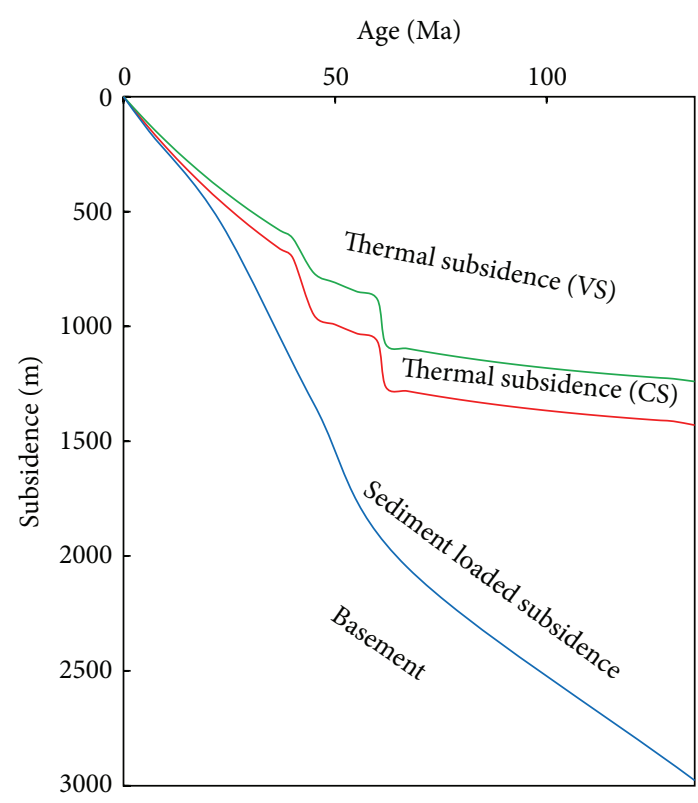

Figure 12: Thermal subsidence curves for models of uniform (CS) and nonuniform (VS) stretching. The blue curve indicates sedimentloaded subsidence.

where, according to [68], the term $x_{n}$ is given by the relation

$$
x_{n}=\gamma+\left\{( 1 - \gamma ) \left[(\delta-\beta) \operatorname{sen} n \pi\left(1-\frac{y}{a \delta}\right)\right.\right.
$$

$$
\begin{aligned}
& \left.+\beta \operatorname{sen} n \pi\left(1-\frac{y}{a \delta}-\frac{1-y / a}{\beta}\right)\right] . \\
& \left.\times \frac{(-1)^{n+1}}{n \pi}\right\}
\end{aligned}
$$

A comparison with (13) revealed the presence of a discrepancy in (15). The correct expression may be written as [64]

$$
\begin{gathered}
x_{n}=\gamma+\left\{( 1 - \gamma ) \left[(\delta-\beta) \operatorname{sen} n \pi\left(1-\frac{y}{a \delta}\right)\right.\right. \\
\left.+\beta \operatorname{sen} n \pi\left(\frac{y}{a \delta}+\frac{1-y / a}{\beta}\right)\right] \\
\left.\times \frac{(-1)^{n+1}}{n \pi}\right\} .
\end{gathered}
$$

The stretching factors listed in Table 8 were used in deriving paleoheat flow values for the sites of six wells selected in the present work. Comparison of results obtained using (13) and (14) reveals that the overall trends of paleoheat flow derived from CS and VS models are similar. However, VS model leads to heat flow values that are in general higher, a consequence of the larger stretching factors in the subcrustal layer.

The variations of paleoheat flow values with elapsed time are illustrated in Figure 13, for the six sites considered in the present work. It reveals heat flow in the range of 100 to $130 \mathrm{~mW} / \mathrm{m}^{2}$ during the initial rift phase, which lasted from 130 to $100 \mathrm{Ma}$. During the transition stage which followed this initial phase, heat flow decreased systematically with 


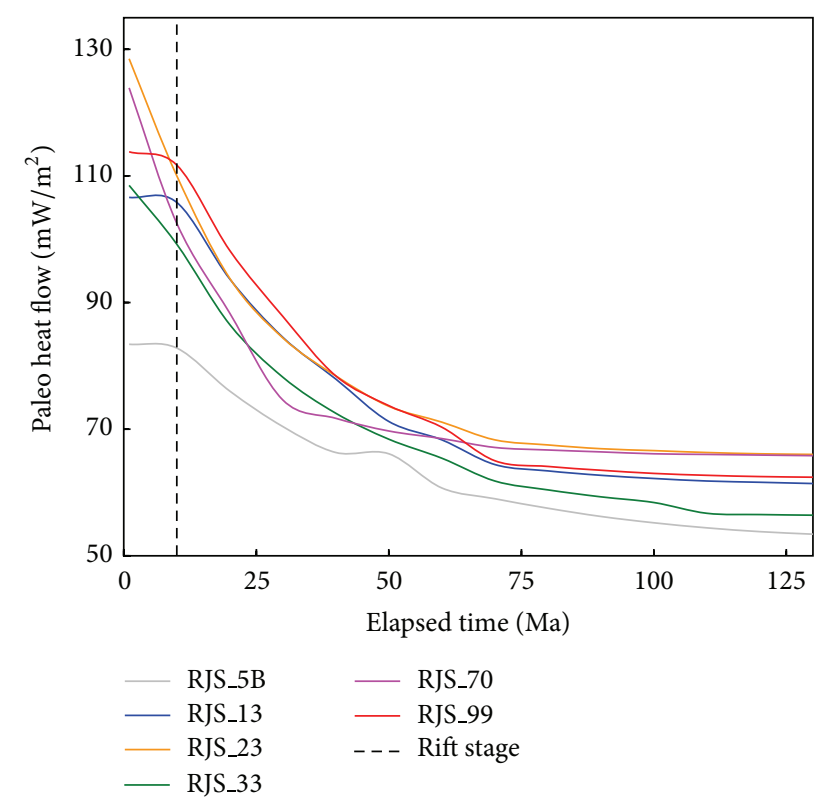

FIGURE 13: Evolution of heat flux as a function of elapsed time calculated on the basis of the variable stretching model [68] for sites of six wells indicated in the map of Figure 4.

age, reaching values of less than $70 \mathrm{~mW} / \mathrm{m}^{2}$, at $60 \mathrm{Ma}$. No appreciable changes in heat flow occurred during the final stage, lasting from $60 \mathrm{Ma}$ to present day. It is important to point out that heat flow variations illustrated in Figure 13 refer mainly to localities in the eastern parts of the Campos basin. As mentioned earlier, the present day heat flow in the central parts of this basin is relatively high, reaching values in excess of $90 \mathrm{~mW} / \mathrm{m}^{2}$.

At this point, it is important to draw attention to a potential source of error in the calculation of paleoheat flow based on the model proposed by McKenzie [67]. As pointed out by Cardoso and Hamza [70], the definition of the time constant $\tau$ in the McKenzie model (see (11)) implies that the decay of the transient components of temperature and heat flow during the period immediately following episode of extension is determined by the initial thickness $(L)$ of the lithosphere. This is obviously an inappropriate assumption as the lithospheric thickness immediately after extension is $(L / \beta)$. It returns to the initial value $L$ only after the dissipation of the thermal perturbation produced by the stretching event. In other words, the relevant parameter for heat dissipation from the underlying uplifted asthenosphere is variable.

Cardoso and Hamza [70] proposed that the postextensional growth in the thickness $(a)$ of the lithosphere obeys a relation of the type

$$
a(t)=\frac{L}{\beta}+\left(L-\frac{L}{\beta}\right) \operatorname{erf}(\gamma t),
$$

where erf is the error function and $\gamma$ is a suitable scaling constant. According to (17), the initial (i.e., at time $t=0$ ) value for the thickness of the stretched lithosphere is $(L / \beta)$, while, for large times (i.e., for $t \rightarrow \infty$ ), it tends to the initial value $(L)$ before the stretching event. The error function term arises from the underlying assumption that solidification process of the intruded asthenosphere during the period following extension has similarities with that of a stagnant, semi-infinite fluid. Cardoso and Hamza [70] demonstrated that the correction for thermal time constant leads to postrift heat flow values invariably lower than those predicted by the McKenzie model. However, results of numerical simulations indicate that departures from McKenzie model become significant only in cases where values of stretching parameter are greater than 2 . It is therefore unlikely to be a significant source of error in the results of the present work.

4.4. Paleotemperatures. The temperatures during evolutionary history of the basin have been calculated making use of the relation

$$
T(z, t)=T_{0}+\int_{0}^{z} Q(t) R_{t}(z, t) d z
$$

where $T_{0}$ is the surface temperature, $Z$ the thickness of the layer under consideration, $Q$ the heat flux at time $t$, and $R_{t}$ the thermal resistance of the layer at depth $z$ and time $t$. An example of paleotemperatures is presented in Figure 14 for well RJS-99. In this figure, the dotted lines in red color indicate the isotherms. The numbers beside the isotherms indicate values of paleotemperatures in degrees centigrade. The continuous lines indicate the sequences in the subsidence history of the main sedimentary formations. In case of wells RJS-13, RJS-23, and RJS-70, the isotherms are found mostly to be parallel and subhorizontal. In the case of well RJS-5B, there is a drop in temperature at the time of $30 \mathrm{Ma}$, whereas, in the case of well RJS-33, there is a rise in temperatures. In case of wells RJS-33 and RJS-99, the rise of temperatures occurs at age of $68 \mathrm{Ma}$.

Also included in Figure 14 are time-temperature indices (TTI) of thermal maturation, as per the Lopatin method [71]. Note that the TTI value of 15 , corresponding to onset of oil generation, is encountered at a depth of nearly 3000 meters. The TTI value of 60 , corresponding to peak oil generation, occurs at depth of approximately 4200 meters. The corresponding indices for the remaining five well sites are found to occur at slightly larger depths. Unfortunately, most of these wells (with the exception of RJS-99) are located outside the central rift zone. These wells have not penetrated the deeper sedimentary strata where the source rocks of hydrocarbons are situated. Hence, it has not been possible to estimate ages of peak oil generation in deep seated source rocks of Barremian, Albian, and Turonian periods. Results of numerical simulations using commercial software (e.g., PETROMOD [72]) indicate periods of peak oil generation in the range of approximately 80 to $60 \mathrm{Ma}$ [73]. It is, however, important to point out that such calculations are based on paleoheat flow values derived from the McKenzie model [67]. On the other hand, results of model calculations that incorporate corrections for the variable thermal time constant of the lithosphere (Cardoso and Hamza [70]) point to a lower age range (of 40 to $20 \mathrm{Ma}$ ) for peak oil generation in the Campos basin. 


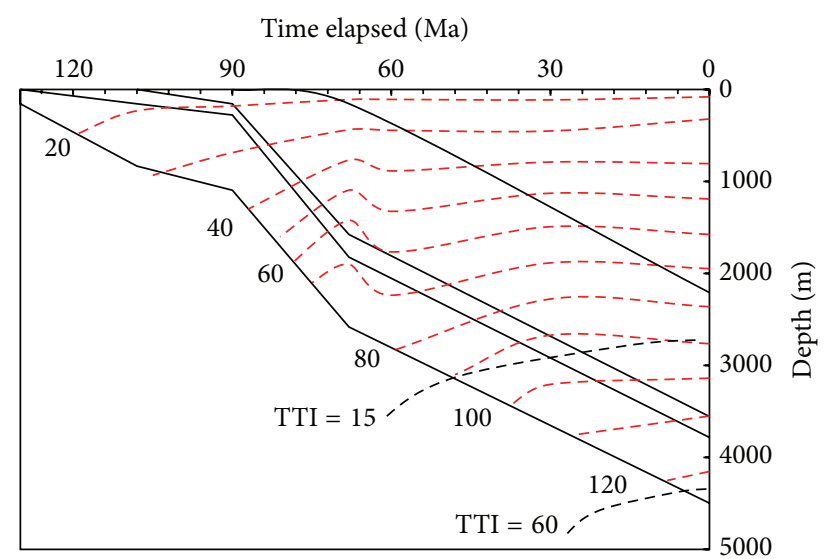

FIGURE 14: Evolution of temperatures at the site of well RJS-99 during the evolutionary history of the Campos basin. The dotted lines in red color indicate the isotherms. The numbers beside the isotherms indicate values of temperatures in degree centigrade. The dashed curves indicate TTI indices of 15 and 60, corresponding, respectively, to onset and peak of oil generation. The continuous lines indicate time-depth sequences in the subsidence history of the main sedimentary formations.

\section{Conclusions}

Analysis of data sets on bottom-hole temperatures, physical properties derived from geophysical well logs, and descriptions of lithologic sequences encountered in drilling operations of deep oil wells has contributed to revised assessments of the geothermal field of the Campos sedimentary basin. According to the results obtained, the present day geothermal gradients in the Campos basin vary from 24 to $41^{\circ} \mathrm{C} / \mathrm{km}$, while crustal heat flow values are in the range of 50 to $100 \mathrm{~mW} / \mathrm{m}^{2}$. The regional distribution of available data sets has allowed identification of a northsouth trending zone of relatively high geothermal gradients and heat flow in the central part of the Campos basin. This anomalous zone has the shape of an arcuate belt and is roughly coincident with areas of known occurrences of oil and gas deposits. There are indications that the high heat flow belt is not restricted to the Campos basin but extends to the south into the Santos basin and also to the north into the Espirito Santo basin. The existence of a major geothermal belt adjacent to the continental margin of southeast Brazil is an altogether surprising result as it departs from the usual trend of decreasing heat flow age of ocean crust $[74,75]$. The width of the high heat flow zone is narrow implying that the heat source is located at shallow depths in the upper crust and is relatively recent. The mechanism responsible for high heat flow with such characteristics brings into question the nature of central rift zone of the Campos basin. It appears to have the characteristics of a unique "heat-leaking plate boundary," situated between the continental and oceanic segments of the South American lithosphere.

The present work also provides improved assessment of the subsidence history at six localities in the Campos basin. The results have allowed determination of paleothermal conditions of the basement beneath the sediments. There are indications that heat flow was substantially higher (in excess of $100 \mathrm{~mW} / \mathrm{m}^{2}$ ) during the initial rifting episode, which lasted from approximately 130 to $110 \mathrm{Ma}$. The transition stage, which followed the initial rift stage, is characterized by systematic decrease in heat flow, reaching values of less than $70 \mathrm{~mW} / \mathrm{m}^{2}$ at $60 \mathrm{Ma}$. No appreciable changes in heat flow seem to have occurred during the final stage in most parts of the Campos basin. However, present heat flow is high within the central rift zone, pointing to recent thermal reactivation of the contact zone between the oceanic and continental segments of the South American lithosphere. Thermal maturation indices (TTI) calculated on the basis of Lopatin method indicate that significant oil and gas generation occur at depths greater than $3 \mathrm{~km}$. The age of peak oil generation, estimated on the basis of McKenzie model of lithospheric extension, is found to fall in the range of 80 to $60 \mathrm{Ma}$. However, the age of peak oil generation is found to be less than $40 \mathrm{Ma}$, if we allow for variable thermal relaxation periods for the extended lithosphere.

\section{Conflict of Interests}

The authors declare that there is no conflict of interests regarding the publication of this paper.

\section{Acknowledgments}

The present work was carried out as part of M.S. Thesis Project of the first author, who has been a recipient of a scholarship granted by CAPES, during 2005-2008. Thanks are due to Mr. Silvio Zembruscki, late Geologist of PETROBRÁS, for exchange of information on bottom-hole temperature data of oil wells in sedimentary basins of Brazil. The National Agency for Petroleum (ANP) provided data on geophysical logs of six oil exploration wells in the Campos basin. Information on ocean water temperatures along the coastal area of southeast Brazil was provided by Directorate of Hydrograph and Navigation (DHN). The authors thank Engineer Fábio Vieira (National Observatory, Rio de Janeiro, Brazil) for complementary data analysis and Blair Bryce (Marketing Manager of Modus Medical Devices Inc., Canada) for help in reformatting the graphics. The second author is recipient of a research scholarship granted by Conselho Nacional de Desenvolvimento Cientifico e Tecnológico, CNPq (Project no. 301865/2008-6; Produtividade de Pesquisa, PQ). The authors thank Dr. Andrés Papa, Coordinator of the Department of Geophysics of Observatório Nacional, ON/MCT, for institutional support.

\section{References}

[1] C. H. L. Bruhn, C. Cainelli, and R. M. D. Matos, "Habitat do Petróleo e Fronteiras Exploratórias nos Rifts Brasileiros," Boletim de Geociências da Petrobrás, vol. 2, pp. 217-253, 1988.

[2] H. D. Rangel, F. A. L. Martins, F. R. Esteves, and F. J. Feijó, "Bacia de Campos," Boletim de Geociências da Petrobrás, vol. 8, no. 1, pp. 203-217, 1994. 
[3] E. J. Milani, J. A. S. L. Brandão, P. V. Zalán, and L. A. P. Gamboa, "Petróleo na margem continental brasileira: geologia, exploração, resultados e perspectivas," Revista Brasileira de Geofísica, vol. 18, no. 3, pp. 351-396, 2000.

[4] E. M. Meister, "Gradientes geotérmicos nas bacias sedimentares Brasileiras," Boletim Tecnico da Petrobrás, vol. 16, no. 4, pp. 221232, 1973.

[5] J. Rossi Filho, "Mapa de gradiente geotérmico na plataforma continental brasileira," Internal Report, Centro de Pesquisas da PETROBRÁS - CENPES/SUPEP/DIVEX/SEGEL, 1981.

[6] S. G. Zembruscki and C. H. Kiang, "Gradiente geotérmico das bacias sedimentares brasileiras," Boletim de Geociências da Petrobrás, vol. 3, no. 3, pp. 215-227, 1989.

[7] S. Ross and J. L. Pantoja, "Estudo geotérmico da bacia de Campos," Internal Report, PETROBRÁS, DEPEX, DISUD, Vitória (ES), Brazil, 1978.

[8] R. J. Jahnert, "Gradiente geotérmico da Bacia de Campos," Boletim de Geociências da Petrobrás, vol. 1, no. 2, pp. 183-189, 1987.

[9] R. A. Cardoso and V. M. Hamza, "Gradiente e fluxo geotérmico da plataforma continental da região sudeste do Brasil," in Proceedings of the 8th International Congress of the Brazilian Geophysical Society, Rio de Janeiro, Brazil, 2003.

[10] A. J. L. Gomes and V. M. Hamza, "Geothermal gradient and heat flow in the state of Rio de Janeiro," Brazilian Journal of Geophysics, vol. 23, no. 4, pp. 325-347, 2008.

[11] F. P. Vieira, R. R. Cardoso, and V. M. Hamza, "Global heat loss: new estimates using digital geophysical maps and GIS techniques," in Proceedings of the 4th Brazilian Symposium on Geophysics, pp. 14-17, Brasília, Brazil, November 2010.

[12] F. P. Vieira and V. M. Hamza, "Global heat flow: comparative analysis based on experimental data and theoretical values," in Proceedings of the 12th International Congress of the Brazilian Geophysical Society, Rio de Janeiro, Brazil, August 2011.

[13] F. F. M. de Almeida, "Origem e evolusão da plataforma brasileira," Tech. Rep. 241, Boletim da Divisão de Geologia e Mineralogia, Departamento Nacional da Produção Mineral, Rio de Janeiro, Brazil, 1967.

[14] G. O. Estrella, "O estagio, "rift" nas bacias marginais do leste brasileiro," in Proceedings of the 26th Brazilian Geological Congress, vol. 3, pp. 29-34, 1972.

[15] H. E. Asmus and F. C. Ponte, "The Brazilian marginal basins," in The Ocean Basins and Margins, Volume 1: The South Atlantic, A. E. M. Nairn and F. G. Stehli, Eds., pp. 87-133, Springer, New York, NY, USA, 1973.

[16] F. C. Ponte and H. E. Asmus, "The Brazilian marginal basinscurrent state of knowledge," Brazilian Academy of Sciences, vol. 48, supplement, pp. 215-240, 1976.

[17] F. F. M. de Almeida, "The system of continental rifts bordering the Santos Basin, Brazil," Anais da Academia Brasileira de Ciências, vol. 48, supplement, pp. 14-26, 1976.

[18] P. D. Rabinowitz and J. la Brecque, "The Mesozoic South Atlantic ocean and evolution of its continental margins.," Journal of Geophysical Research B, vol. 84, no. 11, pp. 5973-6002, 1979.

[19] T. P. Gladczenko, K. Hinz, O. Eldholm, H. Meyer, S. Neben, and J. Skogseid, "South Atlantic volcanic margins," Journal of the Geological Society of London, vol. 154, no. 3, pp. 465-470, 1997.

[20] H. E. Asmus and R. Porto, "Classificação das bacias sedimentares brasileiras segundo a tectônica de placas," in Proceedings of the 26th Brazilian Geological Congress, vol. 2, pp. 67-90, 1972.
[21] C. W. M. Campos, F. C. Ponte, and K. Miura, "Geology of the Brazilian continental margin," in The Geology of Continental Margins, C. A. Burk and C. L. Drake, Eds., pp. 447-461, Springer, New York, NY, USA, 1974.

[22] H. A. O. Ojeda, "Structural framework, stratigraphy, and evolution of Brazilian marginal basins," American Association of Petroleum Geologists Bulletin, vol. 66, no. 6, pp. 732-749, 1982.

[23] R. L. M. Azevedo, J. Gomide, and M. C. Viviers, "Geo-história da Bacia de Campos, Brasil: do Albiano ao Maastrichtiano," Revista. Brasileira de Geociências, vol. 17, no. 2, pp. 137-146, 1987.

[24] J. D. Milliman, "Morphology and structure of upper continental margin off southern Brazil," American Association of Petroleum Geologists Bulletin, vol. 62, no. 6, pp. 1029-1048, 1978.

[25] F. C. Ponte and H. E. Asmus, "Geological framework of the Brazilian continental margin," Geologische Rundschau, vol. 67, no. 1, pp. 201-235, 1978.

[26] W. U. Mohriak, M. R. Mello, G. D. Karner, J. F. Dewey, and J. R. Maxwell, "Structural and stratigraphic evolution of the Campos Basin, offshore Brazil," in Extension Tectonics and Stratigraphy of the North Atlantic Margins, AAPG Special Volume, chapter 38, Analogs, pp. 577-598, American Association of Petroleum Geologists Memoir, 1989.

[27] W. U. Mohriak, M. R. Mello, J. F. Dewey, and J. R. Maxwell, "Petroleum geology of the Campos Basin, offshore Brazil," Geological Society of London, Special Publication, vol. 50, no. 1, pp. 119-141, 1990.

[28] W. U. Mohriak, A. Z. N. de Barros, and A. Fujita, "Magmatismo e tectonismo Cenozóico na região de Cabo Frio, RJ," in Proceedings of the 36th Brazilian Geological Congress, vol. 6, pp. 2873-2885, 1990.

[29] A. M. P. Mizusaki and W. U. Mohriak, "Seqüências Vulcanosedimentares na Região da Plataforma Continental de Cabo Frio, RJ," in Proceedings of the 37th Brazilian Geological Congress, vol. 2, pp. 468-469, 1992.

[30] J. L. P. Moreira, C. A. Esteves, J. J. G. Rodrigues, and C. S. Vasconcelos, "Magmatismo, sedimentação e estratigrafia da porção norte da Bacia de Santos," Boletim de Geociências da Petrobrás, vol. 14, no. 1, pp. 161-170, 2006.

[31] S. G. Oreiro, Magmatismo e sedimentação em uma área na plataforma continental de Cabo Frio, Rio de Janeiro, Brasil, no intervalo Cretáceo Superior-Terciário [M.S. thesis], State Uiversity of Rio de Janeiro, Rio de Janeiro, Brazil, 2002.

[32] Diretoria de Hidrografia e navegação (DHN), Banco Nacional de Dados Oceanográficos-BNDO, Centro de Hidrografia da Marinha, Rio de Janeiro, Brazil, 1998.

[33] S. G. Zembruscki, "Gradiente geotérmico das bacias sedimentares brasileiras," Internal Report of CENPES (PETROBRÁS) 483, Boletim de Geociencias PETROBRAS, 1982.

[34] American Association of Petroleum Geologists, Basic Data from AAPG Geothermal Survey of North America, University of Oklahoma, Norman, Okla, USA, 1976.

[35] F. B. Ribeiro and V. M. Hamza, "Modelling thermal disturbances induced by drilling activity: advances in theory and practice," Brazilian Journal of Geophysics, vol. 4, pp. 91-106, 1986.

[36] A. G. Cavalcante, R. M. Argollo, and H. S. Carvalho, "Correção de Dados de Temperatura de Fundo de Poço (Tfp)," Brazilian Journal of Geophysics, vol. 22, pp. 233-243, 2004.

[37] J. Gallardo and D. D. Blackwell, "Thermal structure of the Anadarko basin," AAPG Bulletin, vol. 83, no. 2, pp. 333-361, 1999. 
[38] D. D. Blackwell and M. Richards, "Geothermal Map of North America," American Association of Petroleum Geologists, scale 1:6, 500, 000, 2004.

[39] V. M. Hamza and F. P. Vieira, "Global distribution of the lithosphere-asthenosphere boundary: a new look," Solid Earth, vol. 3, pp. 1-13, 2012.

[40] Y. R. Marangoni and V. M. Hamza, "Condutividade térmica de sedimentos da plataforma continental sudeste do Brasil," Brazilian Journal of Geophysics, vol. 2, pp. 11-18, 1983.

[41] A. J. L. Gomes and V. M. Hamza, "Avaliação de Recursos Geotermais do Estado do Rio de Janeiro," in Proceedings of the 8th International Congress of the Brazilian Geophysical Society, Rio de Janeiro, Brazil, September 2003.

[42] A. C. del Rey and S. G. Zembruscki, "Hydrothermic study of the Espirito Santo and Mucuri Basins," Boletim de Geociências da Petrobrás, vol. 5, no. 1-4, pp. 25-38, 1991.

[43] S. M. Viana, Fluxo Térmico em uma Bacia Sedimentar da Margem Continental Brasileira, Monografia de GraduaçãoFGEL/UERJ, 1999.

[44] F. Birch and H. Clark, "The thermal conductivity of rocks and its dependence upon temperature and composition," American Journal of Science, vol. 238, pp. 529-558, 1940.

[45] W. Woodside and J. H. Messmer, "Thermal conductivity of porous media, I. Unconsolidated sands, II. Consolidated rocks," Journal of Applied Physics, vol. 32, no. 9, pp. 1688-1706, 1961.

[46] J. J. H. C. Houbolt and P. R. A. Wells, "Estimation of heat flow in oil wells based on a relation between heat conductivity and sound velocity," Geologie en Mijnbouw, vol. 59, no. 3, pp. 215$224,1980$.

[47] G. R. Beardsmore and J. P. Cull, Crustal Heat Flow: A Guide to Measurement and Modelling, Cambridge University Press, 2001.

[48] N. Lu and S. Ge, "Effect of horizontal heat and fluid flow on the vertical temperature distribution in a semi-confining layer," Water Resources Research, vol. 32, no. 5, pp. 1449-1453, 1996.

[49] J. D. Bredehoeft and I. S. Papadopulos, "Rates of vertical groundwater movement estimated from the earth's thermal profile," Water Resources Research, vol. 1, pp. 325-328, 1965.

[50] M. Reiter, "Using precision temperature logs to estimate horizontal and vertical groundwater flow components," Water Resources Research, vol. 37, no. 3, pp. 663-674, 2001.

[51] E. T. Pimentel and V. M. Hamza, "Use of geothermal methods in outlining deep groundwater flow systems in Paleozoic interior basins of Brazil," Hydrogeology Journal, vol. 22, pp. 107-128, 2014.

[52] P. Szatmari, J. C. J. Conceição, M. C. Lana, E. J. Milani, and A. P. Lobo, "Mecanismo tectônico do rifteamento Sul-Atlântico," in Proceedings of the 33rd Brazilian Geological Congress, pp. 15891601, Rio de Janeiro, Brazil, 1984.

[53] P. Szatmari and W. U. Mohriak, "Plate model of post breakup tectono-magmatic activity in SE Brazil and the adjacent Atlantic," in Proceedings of the 1995 National Symposium on Tectonic Studies, vol. 5, pp. 213-214, Gramado (RS), Brazil, 1995.

[54] F. F. M. de Almeida, C. D. R. Carneiro, and A. M. P. Mizusaki, "Correlação do magmatismo das Bacias da Margem Continental Brasileira com o das areas emersas adjacentes," Revista Brasileira de Geociências, vol. 23, no. 3, pp. 125-138, 1996.

[55] W. U. Mohriak, J. M. Macedo, R. T. Castelani et al., "Salt tectonics and structural styles in the Deep-Water province of the Cabo Frio Region, Rio de Janeiro, Brazil," in Salt Tectonics: A Global Perspective, D. G. Jackson, D. G. Roberts, and S. Snelson, Eds., vol. 65, pp. 273-304, American Association of Petroleum Geologists, Memoir, 1996.
[56] W. R. Winter, R. J. Jahnert, and A. B. França, "Bacia de Campos," Boletim de Geociências da Petrobrás, vol. 15, no. 2, pp. 511-529, 2007.

[57] A. Thomaz Filho, A. M. P. Mizusaki, E. J. Milani, and P. Césero, "Rifting and magmatism associated with the South America and Africa Breakup," Revista Brasileira de Geociências, vol. 30, no. 1, pp. 17-19, 2000.

[58] A. T. Filho, P. de Cesero, A. M. Mizusaki, and J. G. Leão, "Hot spot volcanic tracks and their implications for south American plate motion, Campos basin (Rio de Janeiro state), Brazil," Journal of South American Earth Sciences, vol. 18, no. 3-4, pp. 383-389, 2005.

[59] A. A. Bender, U. T. Mello, and C. H. Kiang, "Reconstituição bidimensional da história geológica de bacias sedimentaresteoria e uma aplicação na Bacia de Campos," Boletim de Geociências da Petrobrás, vol. 3, no. 1-2, pp. 67-85, 1989.

[60] H. K. Chang, A. A. Bender, and U. T. Mello, "Origem e evolução termomecânica de bacias sedimentares," in Origem e Evolução de Bacias Sedimentares, G. P. Raja Gabaglia and E. J. Milani, Eds., pp. 49-71, Petrobras, 1990.

[61] F. G. Gonzaga, Simulação Geoquímica 1d ao longo de uma seção geológica da bacia de Campos [M.S. thesis], Federal University of Rio de Janeiro, 2005.

[62] R. A. Cardoso, "Estudo da evolução tectônica e história térmica da plataforma continental do Estado do Rio de Janeiro," Monography of Graduation, State University of Rio de Janeiro, 2005.

[63] R. A. Cardoso and V. M. Hamza, "Evolução Termotectônica da Parte Oeste da Bacia de Campos," in Proceedings of the 9th International Congress of the Brazilian Geophysical Society, pp. 1-6, Salvador, Brazil, September 2005.

[64] R. A. Cardoso, Evolução Termo-Tectônica da Plataforma Continental do Estado do Rio de Janeiro [M.S. thesis], Observatório Nacional, Rio de Janeiro, Brazil, 2007.

[65] M. S. Steckler and A. B. Watts, "Subsidence of the Atlantic-type continental margin off New York," Earth and Planetary Science Letters, vol. 42, pp. 1-3, 1978.

[66] J. G. Sclater and P. A. F. Christie, "Continental stretching: an explanation of the pre-mid-cretaceous subsidence of the Central North Sea Basin," Journal of Geophysical Research, vol. 85, pp. 3711-3739, 1980.

[67] D. McKenzie, "Some remarks on the development of sedimentary basins," Earth and Planetary Science Letters, vol. 40, no. 1, pp. 25-32, 1978.

[68] L. Royden and C. E. Keen, "Rifting process and thermal evolution of the continental margin of Eastern Canada determined from subsidence curves," Earth and Planetary Science Letters, vol. 51, no. 2, pp. 343-361, 1980.

[69] K. M. Cohen, S. Finney, and P. L. Gibbard, International Chronostratigraphic Chart. Version 2013/01, International Commission on Stratigraphy, 2013, http://www.stratigraphy.org/ ICSchart/ChronostratChart2013-01.pdf.

[70] R. R. Cardoso and V. M. Hamza, "A source of error in McKenzie model of lithospheric extension and its implications for petroleum play in sedimentary basins," in Proceedings of the 11th International Congress of the Brazilian Geophysical Society, pp. 1-6, Salvador, Brazil, August 2009.

[71] N. V. Lopatin, "Temperature and geological time as factors of carbonifaction," Izvestiya Akademii Nauk SSSR, Seriya Geologicheskaya, vol. 3, pp. 95-106, 1971.

[72] PETROMOD, "IES GMBH Integrated Exploration Systems," Aachen, Germany, 2006. 
[73] J. L. Dias, J. C. Scarton, F. R. Esteves, M. Carminatti, and L. R. Guardado, "Aspectos da Evolução Tectono-sedimentar e a ocorrência de hidrocarbonetos na Bacia de Campos," in Origem e Evolução de Bacias Sedimentares, G. P. Raja Gabaglia and E. J. Milani, Eds., pp. 333-360, Petrobrás, 1990.

[74] V. M. Hamza, R. R. Cardoso, and C. F. Ponte Neto, "Spherical harmonic analysis of earth's conductive heat flow," International Journal of Earth Sciences, vol. 97, no. 2, pp. 205-226, 2008.

[75] V. M. Hamza, R. R. Cardoso, and C. H. Alexandrino, "A magma accretion model for the formation of oceanic lithosphere: implications for global heat loss," International Journal of Geophysics, vol. 2010, Article ID 146496, 16 pages, 2010.

[76] M. J. Pereira and F. J. Feijó, "Bacia de Santos," Boletim de Geociências da Petrobrás, vol. 8, no. 1, pp. 219-234, 1994.

[77] V. M. Hamza, "Pesquisas geotérmicas na exploração de hidrocarbonetos na Bacia do Paraná," Internal Report of Instituto de Pesquisas Tecnologicas-IPT 17, Instituto de Pesquisas Tecnologicas, 1982. 

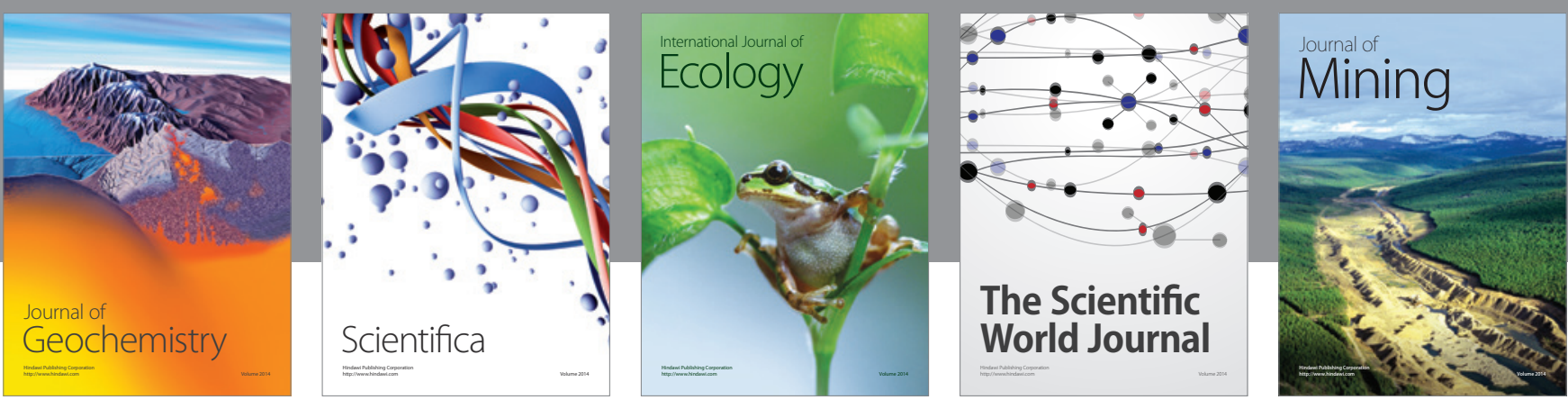

The Scientific World Journal
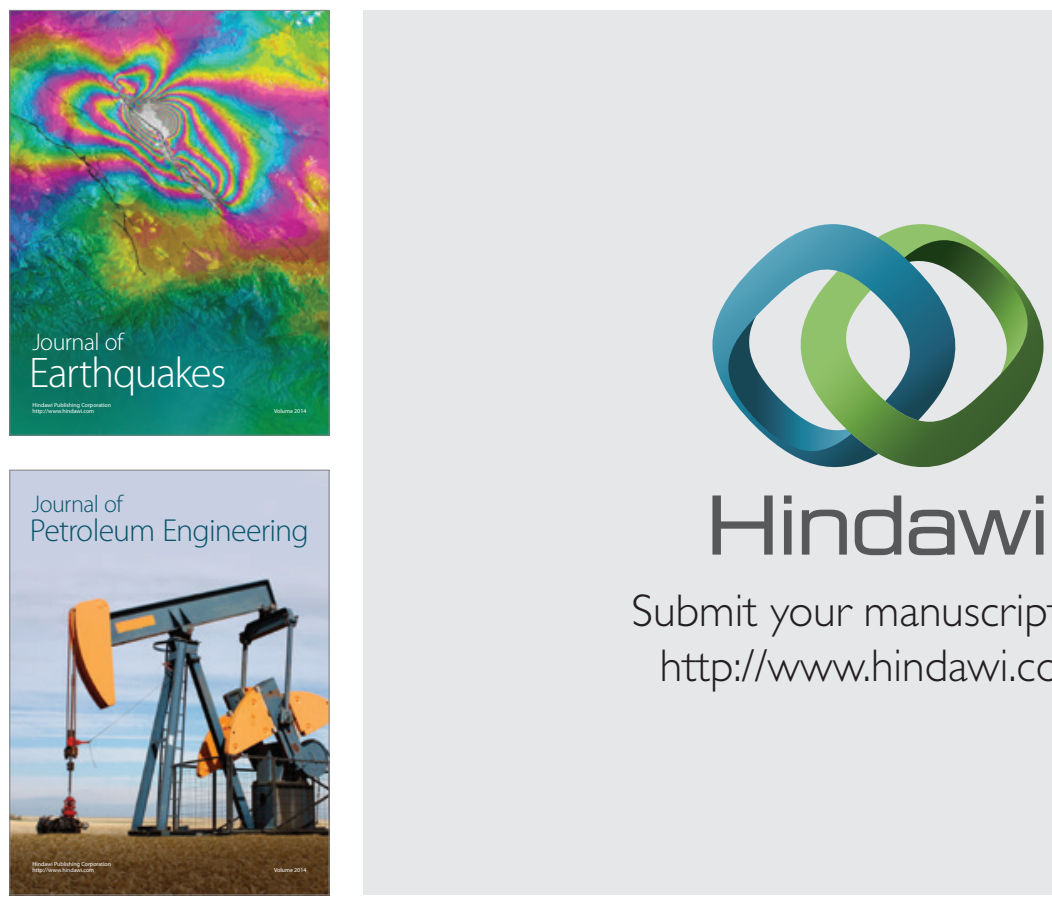

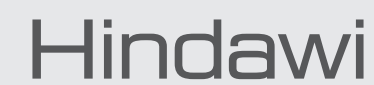

Submit your manuscripts at

http://www.hindawi.com
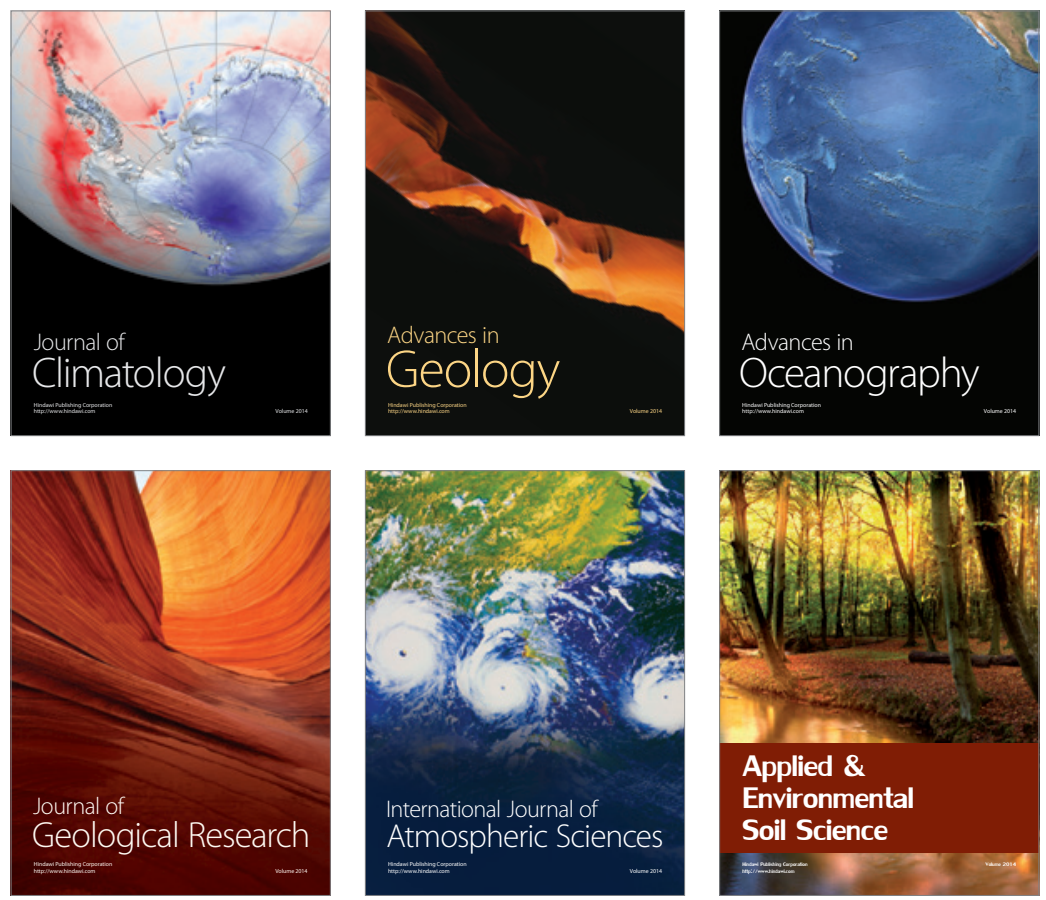
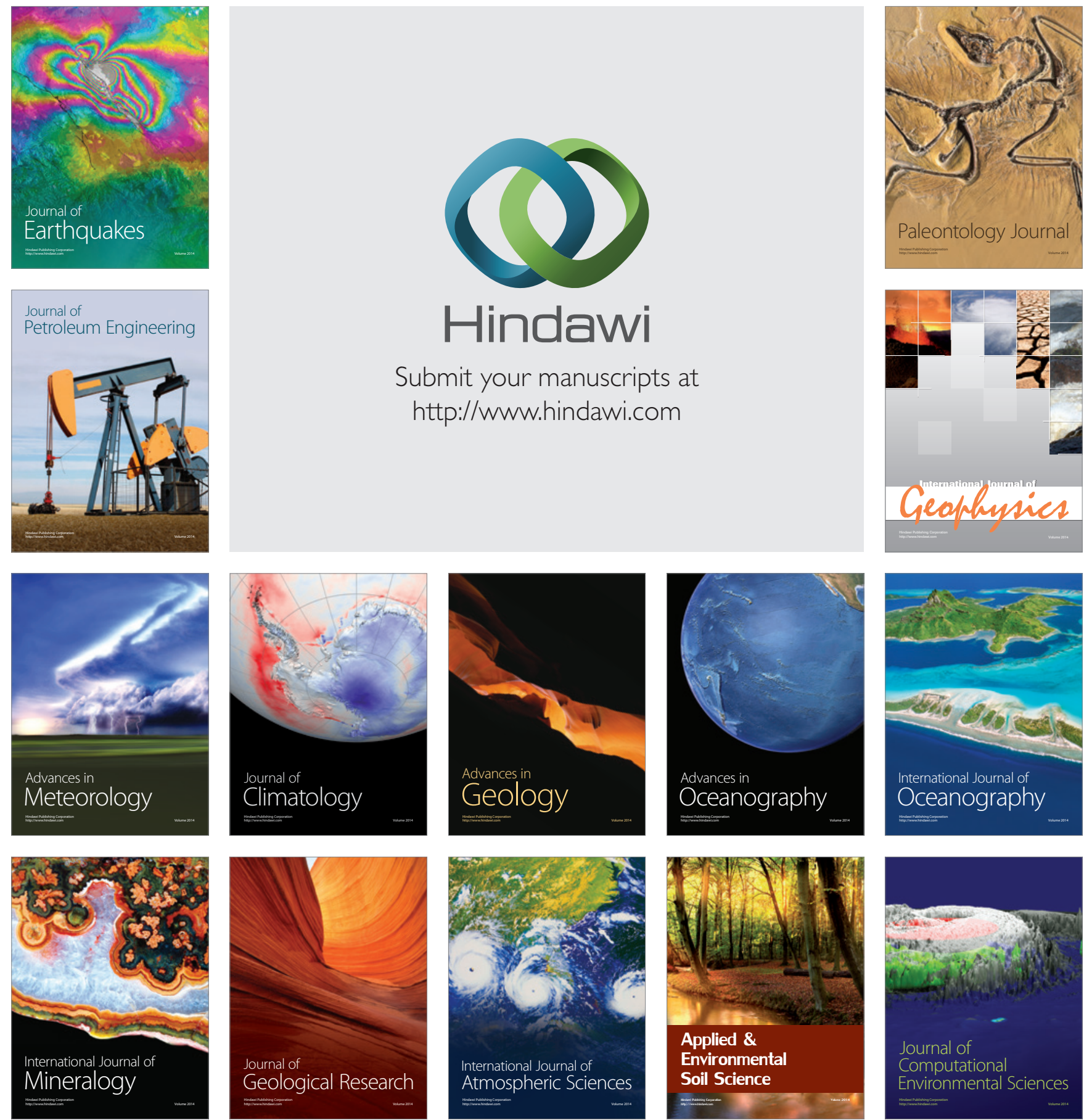